\title{
Ornamentos de platibanda em edificações de Belém entre os séculos XIX e XX: inventário e conservação
}

\author{
Platiband ornaments of cultural buildings in Belém, between the nineteenth and \\ twentieth centuries
}

\author{
TAINÁ CHERMONT ARRUDA' \\ Universidade Federal do Pará / Belém, PA, Brasil
}

\section{THAIS ALESSANDRA BASTOS CAMINHA SANJAD²}

Universidade Federal do Pará / Belém, PA, Brasil

RESUMO: Os ornamentos de cerâmica vitrificada eram usados como elementos decorativos e peças como as estátuas tinham papel alegórico no coroamento das fachadas para destacar ou para caracterizar a função tipológica da edificação ou como símbolo que o proprietário queria transmitir referente aos valores defendidos na época da Revolução Industrial. Os ornamentos nas platibandas simbolizavam riqueza e erudição, por ser atribuídos à elite, desde a época Moderna. A pesquisa teve por objetivo a identificação dos ornamentos de platibanda de cerâmica vitrificada que compõem a arquitetura eclética do Centro Histórico de Belém (Pará) e seu entorno com vistas a traçar subsídios a sua preservação. Buscou-se identificar e localizar os tipos de ornamentos vitrificados existentes no Centro Histórico e seu entorno da cidade de Belém do Pará, por meio de inspeção visual da região, possibilitando analisar e compreender o contexło dessas peças na realidade local. Identificaram-se 225 imóveis com ornamentação de platibanda na área analisada. Fez-se uso de documentos textuais, catálogo impresso, jornais e álbuns do século XIX e XX para fundamentar a pesquisa e identificação dos ornatos. Os ornamentos de cerâmica vitrificada sofrem um acelerado processo de desaparecimento por estarem expostos nas platibandas das edificações, uma vez que estão mais vulneráveis à ação intempérica, seja ela física, química ou mineralógica, e à ação antrópica, inclusive atos de vandalismo. Esses ornamentos de cerâmica vitrificada são exemplares importantes do patrimônio cultural de Belém, por serem evidência da influência europeia na região, mais especificamente portuguesa, além de serem produtos do desenvolvimento técnico do material e simbólico do século XIX, que merecem urgentes ações de preservação.

\begin{abstract}
1. Arquiteta e urbanista, mestra pelo Programa de Pós-Graduação em Arquitetura e Urbanismo da Universidade Federal do Pará. Bolsista da Fundação Amazônia Paraense de Amparo à Pesquisa (FAPESPA) Endereço: Rua Augusto Corrêa, 1, Universidade Federal do Pará/ Instituto de Tecnologia/ Labo-ratório de Conservação, Restauração e Reabilitação. E-mail: <tainachermontarru da@hotmail.com>.

2. Arquiteta e Urbanista, professora doutora do Programa de Pós-Graduação em Arquitetura e Urbanismo da Universidade Federal do Pará. Endereço: Rua Augusto Corrêa, 1 Universidade Federal do Pará/ Instituto de Tecnologia/ coordenadora de pesquisa do Laboratório de Conservação, Restauração e Reabilitação (LACORE) da UFPA, E-mail: $<$ thais@ufpa.br>.
\end{abstract}


PALAVRAS-CHAVE: Ornamentos de platibanda. Cerâmica vitrificada. Centro Histórico. Belém. Preservação.

ABSTRACT: The vitrified ceramic ornaments were used as decorative elements and pieces such as statues, had allegorical paper in the crowning of the facades to highlight or to characterize the typological function of the building or as a symbol that the owner wanted to convey referring to the values defended at the time of the Industrial Revolution. The ornaments on the platibands formed a set of pieces with allegorical meanings, which symbolized wealth and erudition, to be attributed to the elite, since the Modern era. The objective of this research was to identify the ornaments made of glazed ceramic that make up the eclectic architecture of the Historic Center of Belém (Pará) and its surroundings with a view to tracing subsidies for its preservation. We sought to identify and locate the types of vitrified ornaments existing in the Historic Center and its surroundings of the city of Belém do Pará, through a visual inspection of the region, making it possible to analyze and understand the context of these pieces in the local reality. A total of 225 properties with ornamental plaice were identified in the analyzed area. The use of textual documents, printed catalogs, newspapers and albums of the 19th and 20th century was used to support research and identification of ornaments. Vitrified ceramic ornaments suffer an accelerated process of disappearance because they are exposed in the building panels, since they are more vulnerable to intemperate action, be it physical, chemical or mineralogical, and anthropic action, including acts of vandalism. These glazed ceramic ornaments are important examples of the cultural heritage of Belém, as they are evidence of the European influence in the region, more specifically Portuguese, besides being products of technical development of the material and symbolic of the nineteenth century, which deserve urgent preservation actions.

KEYWORDS: Platiband ornaments. Glazed pottery. Historic center. Belém (Brazil). Preservation.

\section{INTRODUÇÃO}

Ornamentos são elementos que têm por função a decoração da construção. Também denominados de adornos, ornatos ou parâmetros, ${ }^{3}$ estão também vinculados às manifestações dos estilos arquitetônico neoclássico e eclético ocorrentes no Brasil do século XIX e XX, sendo fundamentais para a caracterização das edificações vinculadas a esses estilos.

O uso de ornamentos na parte externa das edificações originou-se em vilas renascentistas italianas, expandindo-se pela Europa Ocidental. Nesse período histórico encontram-se os exemplos mais grandiosos da ornamentação de fachadas e espaços públicos baseados em repertórios inspirados no império romano (tradição 
clássica). Nota-se que estes ornatos foram usados principalmente em palácios maneiristas e barrocos. As peças de ornamentação eram confeccionadas de material nobre como pedras, preferencialmente o mármore de Carrara, e fabricadas por artistas exímios. ${ }^{4}$

No Brasil, constata-se o uso de ornamentos em platibandas a partir dos Oitocentos, sendo frequente em prédios públicos e religiosos (Figuras 1 e 2), nas quais se utilizou inicialmente como matéria-prima a pedra.

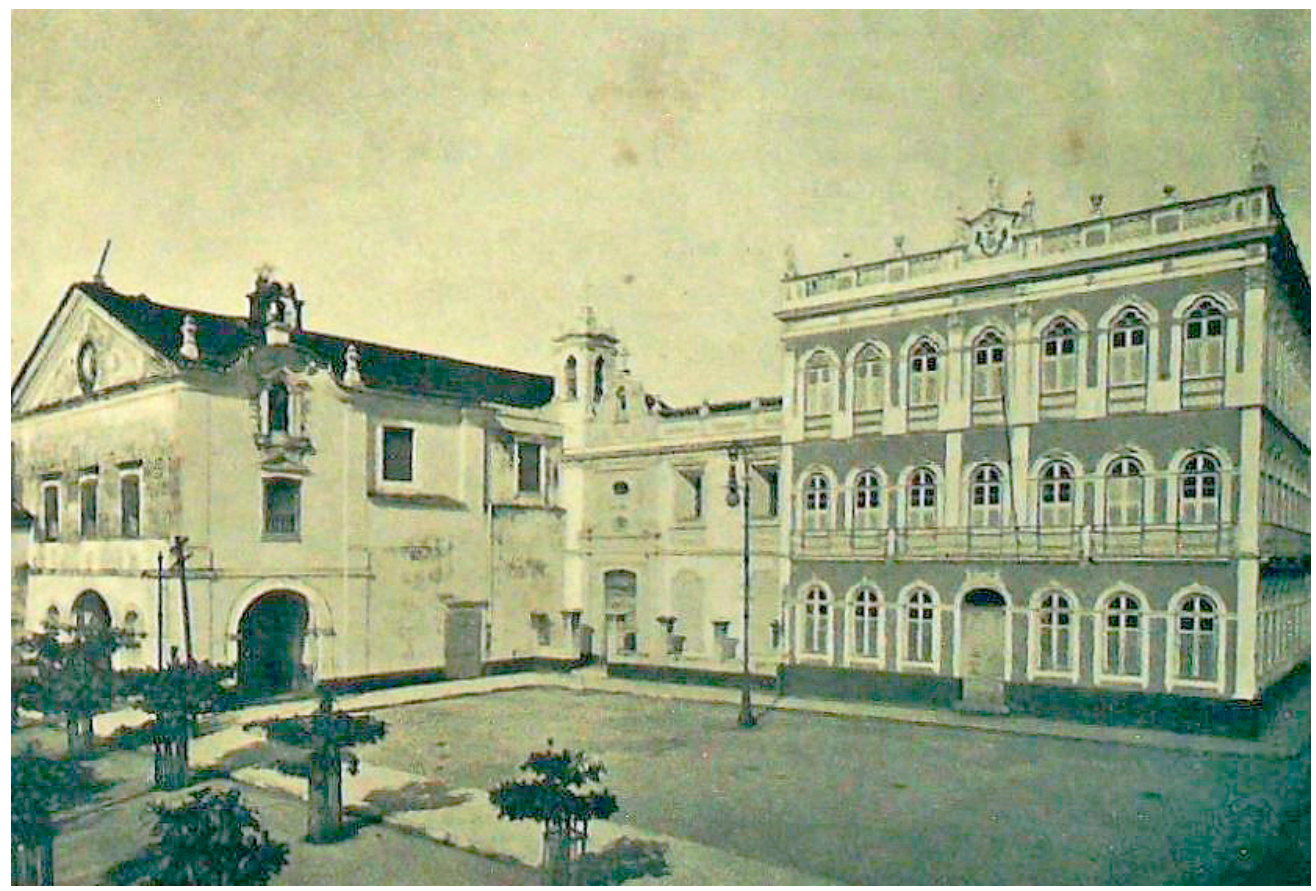

Figura 1 - Igreja de Santo Antônio e Hospital da Ordem $3^{a}$ em Belém, com estatuetas no coroamento da igreja e globos e pinhas ornando o hospital. Fonte: Governo... (1899)

No decorrer do século XIX, o uso de ornamentos de estatuária para platibandas em cerâmica, tanto no Brasil quanto em Portugal, segundo Pais ${ }^{5}$ e Magalhães, ${ }^{6}$ vincula-se ao progresso e à evolução da Revolução Industrial. Tais estátuas são de diferentes origens, técnicas, materiais e estão associadas a práticas simbólicas desse período.?

$\bigcirc$ uso de azulejaria na fachada das edificações residenciais em Portugal e no Brasil gerou um incremento na adição dos ornamentos cerâmicos, ${ }^{8}$ que antes eram usados apenas na decoração de jardins e que passaram a ser cada vez mais utilizados no coroamento de platibandas. ${ }^{9}$

As fachadas das edificações luso-brasileiras do século XIX foram ornadas de inúmeras maneiras, com a preocupação de estabelecer padrões quanto ao
4. Ver Ana Maria Portela Domingues (2009).

5. Ver Alexandre Nobre Pais (2012).

6. Ver Cristiane Maria Magalhães (2014).

7. Ver Cristiane Maria Magalhães (2014).

8. Ver Anna Cristina Rodopiano de Carvalho e Arnaldo Ferreira Marques Junior (2011).

9. Ver Kelly Cristina Scolari e Margarete Regina Freitas Gonçalves (2013). 


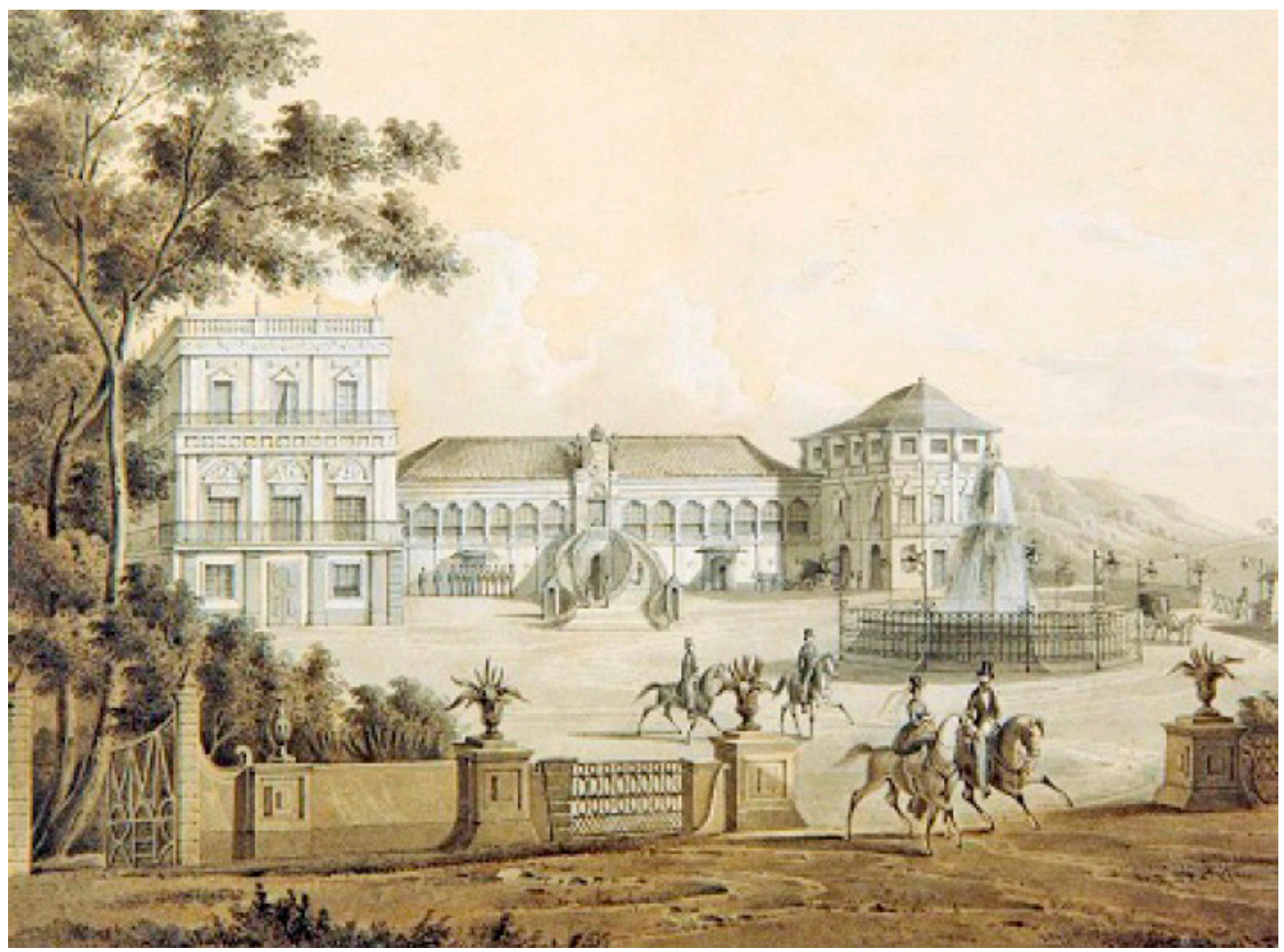

Figura 2 - Palácio da Quinta da Boa Vista ou Quinta de São Cristóvão, no Rio de Janeiro, com estátuas no coroamento da fachada à esquerda e vasos encimando as colunas do muro. Frielieux ca. 1835. Fonte: Gilberto Ferrez (2000, p. 122).

10. Ver Alexandre Mascarenhas (2008).

11. Ver Cristiane Maria Magalhães (2014).

12. Ver Alexandre Mascarenhas (2014). uso e à função da edificação simbolizados na sua decoração, por meio do revivalismo, no que se denominava de arquitetura que fala por si mesma ou architettura parlante. ${ }^{10}$

No Brasil, como consequência da Revolução Industrial na Europa, os ornamentos foram vendidos em catálogos, como produto de consumo, oriundos principalmente das fábricas portuguesas. Não havia produção local até metade do século XX. O grande fluxo de anúncios de negociantes e armazéns de artefatos cerâmicos em jornais, catálogos, almanaques, revistas e exposições universais e industriais indica a receptividade que esses ornamentos recebiam em meados do século XIX. " Segundo Mascarenhas, ${ }^{12}$ havia uma importação intensa de peças industrializadas de todos os materiais para o Brasil, em forma de estátuas, vasos, balaústres, globo, pinhas, com o intuito de "embelezar" as edificações brasileiras. 
Domingues sugere que em Portugal o uso de fachadas azulejadas, no período da consolidação do Romantismo, influenciou o emprego de estátuas e vasos para a decoração das fachadas principais. ${ }^{13}$ Eram usados ricos elementos figurativos com alegorias no coroamento das fachadas para destacar a função do edifício, caracterizando-o e transmitindo uma mensagem determinada para o transeunte.

As classes médias passam a desfrutar desses elementos em suas fachadas em um período mais tardio, ${ }^{14}$ apenas selecionando as estatuetas e ornamentos nos catálogos das fábricas, que muitas vezes não as informavam sobre a simbologia que representavam (Figura 3); assim, empregavam muitas vezes de forma errônea, e sem uma sequência lógica, a mensagem que tais esculturas deveriam transmitir.
13. Ver Ana Maria Portela Domingues (2009).

14. Ver Ana Maria Portela Domingues (2009).

15. Ver Ana Maria Portela Domingues (2009).

16. Ver Kelly Cristina Scolari e Margarete Regina Freitas Gonçalves (2013).

17. Ver Ana Maria Portela Domingues (2009).

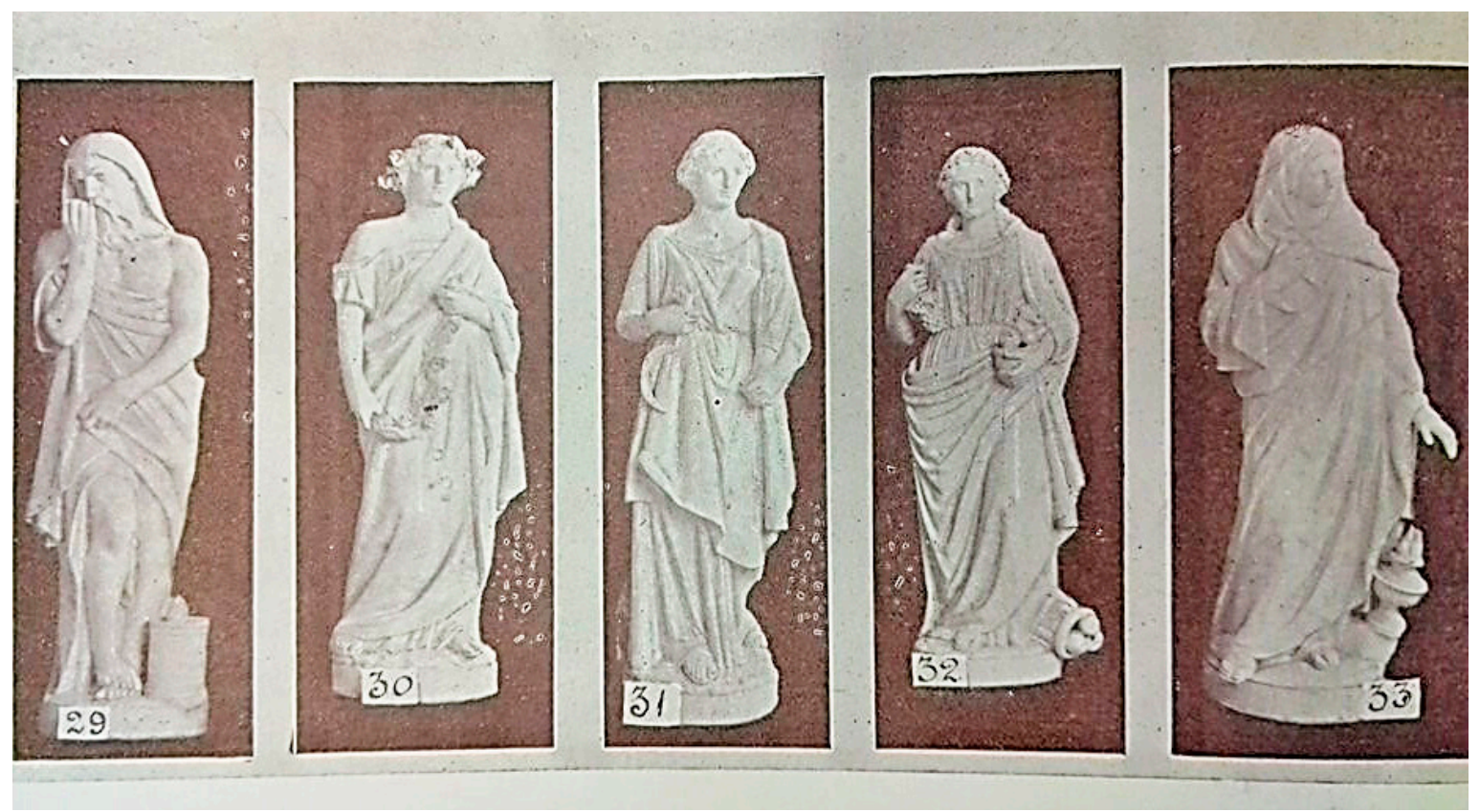

Figura 3 - Esculturas de modelo neoclássico em faiança. Fonte: Catálogo da fábrica de cerâmica e fundição das Devesas - Antonio Almeida da Costa \& Cia.. Vila Nova de Gaya (1910).

Sabe-se que em Portugal tal elemento foi utilizado fortemente no período do Romantismo até o início do século XX, segundo Domingues. ${ }^{15}$ No Brasil, durante a metade do século XX, as importações decaíram, devido ao desenvolvimento da indústria ceramista nacional ${ }^{16}$ (Figura 4).

A presença de ornamentos no coroamento das edificações atribuía a mesma o efeito de arquitetura inspirada na Antiguidade Clássica, especialmente no império romano. ${ }^{17}$ 
18. Ver Ana Maria Portela Domingues (2009).

19. Ver Carmen Lúcia Valério Cal (1989).

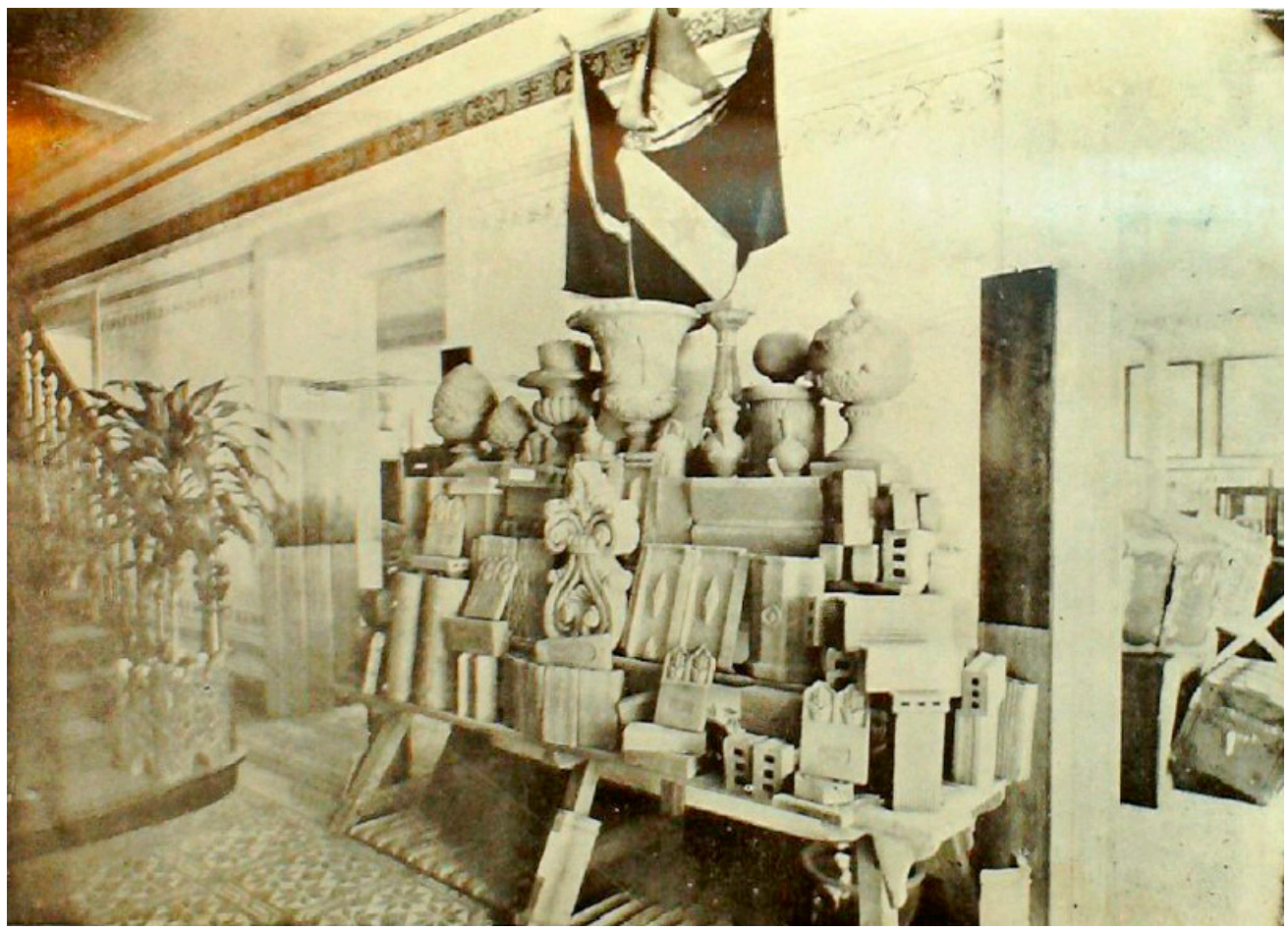

Figura 4 - Seção de cerâmicas e mosaicos da Exposição Paraense no Certâmen Nacional de 1908. Fonte: Jacques Ourique (1908, p. 112$).$

A prevalência do uso desses ornatos vitrificados nas platibandas em determinadas regiões está associada a fenômenos sociais, segundo Domingues, ${ }^{18}$ por tratar-se de peças com valor muito elevado para a época. As peças cerâmicas localizadas nas platibandas das edificações das áreas mais antigas de Belém do Pará demonstram a influência cultural de Portugal no Brasil (Figura 5).

Em Belém, durante o período da borracha, houve um intenso enriquecimento da elite, a qual passou a consumir inúmeros artefatos de origem europeia, inclusive para ornamentação arquitetônica. Com isso, tanto imigrantes europeus como os próprios brasileiros que viajavam para o exterior importavam elementos construtivos para as suas edificações. ${ }^{19}$ No caso de ornamentos de fachada, é possível observar várias peças de cerâmica em platibandas de edifícios históricos de estilo eclético, inclusive contendo a inscrição da fábrica portuguesa, como exemplo, a Fábrica das Devesas, de onde muitas peças eram importadas e vendidas nos armazéns da cidade.

No que tange aos elementos decorativos de platibanda, existia ainda produção local, que, no entanto, não era de produtos cerâmicos vitrificados, sendo muito provavelmente de cantaria ou de argamassa, como eram divulgados nos 
anúncios publicitários nos jornais do século XIX e XX (Figuras 6 a 8) e vendidos em lojas de materiais construtivos e armazéns locais (Figuras 9 a 11 ).

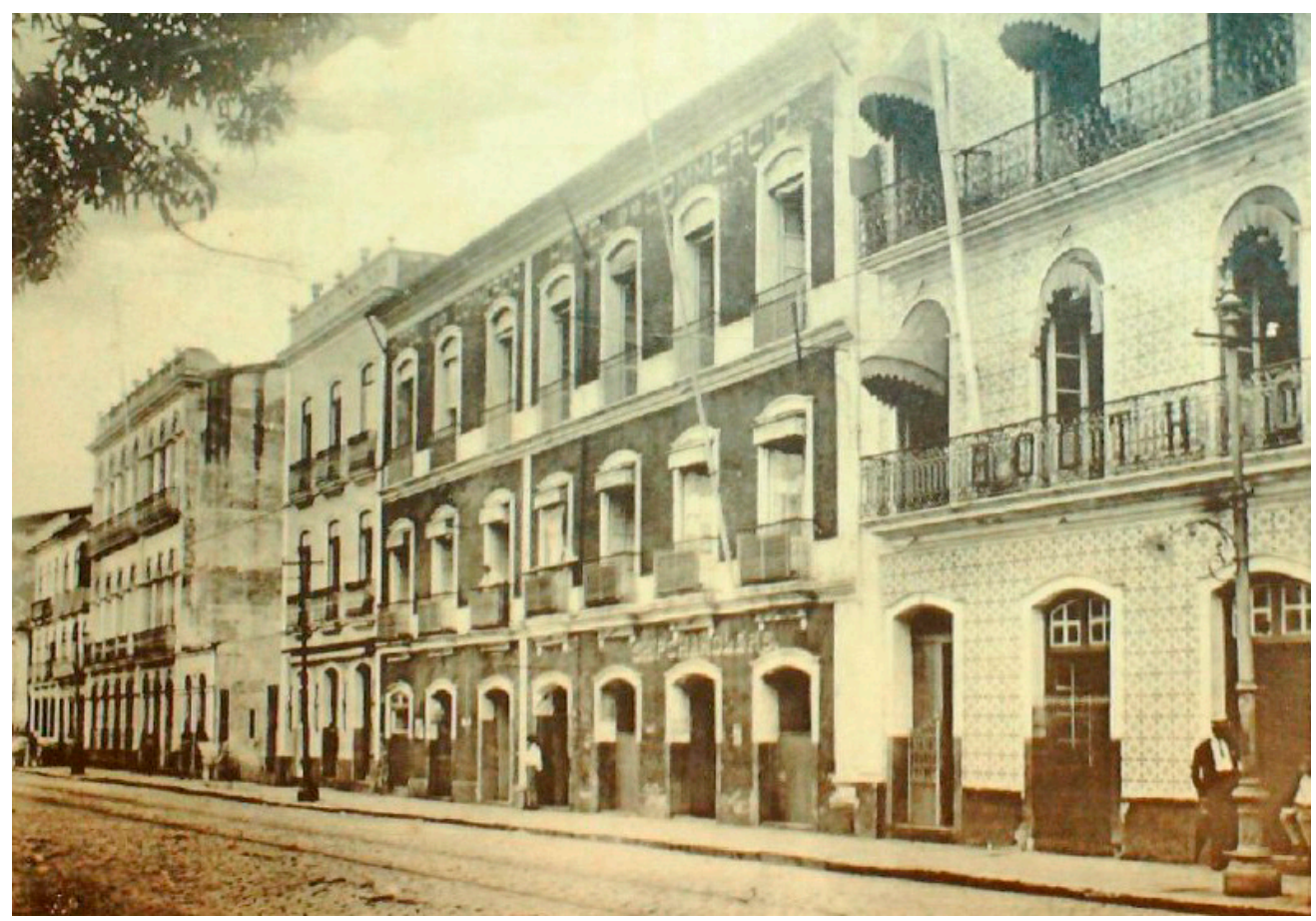

Figura 5 - No centro do centro comercial, Rua da Indústria, 11-15, e Boulevard da República, 54-56, bem em frente ao rio Guajará, em Belém do Pará. Fonte: Indicador Illustrado do Estado do Pará - Parte II (1910).

Uma lei editada no início do século XX foi determinante para ampliar o uso dos ornamentos. No relatório municipal de 1905 do então intendente de Belém, Antônio Lemos, consta a Lei n 419, de 15 de dezembro, a qual determinava que as novas construções fossem edificadas com platibandas, ou mesmo as já existentes adaptadas de modo que as águas pluviais dos telhados não fossem mais lançadas diretamente nas vias públicas por questão de higiene. A lei exigia que, em quaisquer melhoramentos a serem executados nas residências, só seriam aprovados se incluíssem a construção de platibandas com sistema de calhas. ${ }^{20}$

Apesar dessa recomendação, o exagero nas ornamentações no coroamento das edificações, segundo o relatório apresentado ao Conselho Municipal de Belém na sessão de 15 de novembro de 1905, considera que os proprietários das casas estavam a "sobrecarregar a platibanda dos prédios de estetuetas [sic] de gêsso ou de louça, mais ou menos finas, quase sempre grotescas". ${ }^{21} \bigcirc$ intendente acreditava que era de mau gosto ornar os frontispícios das casas com figuras humanas, animais ferozes ou animais domésticos, por defender que o belo estaria naquilo
20. Ver Município de Belém (1905)

21. RELATÓRIO MUNICIPAL, 1905 apud CRUZ, 1971, p. 121. 


\section{Marmoraria Luzitana J. J. SILV}

Grandes officinas mechapicas, movidas por energia electrica, á Rua Padre Prudencio, $\mathbf{N}^{\circ} 13$ e 15 , e Rua 28 de Setembro, $\mathbf{N}^{\circ} \mathbf{3}$, com Eucouraal em frente ao Cemiterio de Santa Izabel.

Os proprietarios d'estes importantes estabelecimentos, os primeiros em todo Brazil e os mais aperfeiçoados e completos da Europa e da America, avisam ao Publico em geral que, tendo passado por grande reforma as suas officinas, acham-se hoje montadas com machinismos para fabricar, com brevidade e perfeiçāo, qualquer trabalho em marmore e cantaria, por preços baratissimos, o que não podiam fazer até hoje, comı o trabalho manual.

Diante dos modicos preços por que estamos manufacturando todas as obras de marmore e pedra, nigguem deixara de render a devida homenagem aos seus entes queridos, nem de empregar os nossos artefactos na construcçåo de seus predios, balaustradas, escadarias, frentes completas, moveis, balcőes de estabelecimentos commerciaes, etc, etc, visto o bello e surprehendente aspecto que dăo os trabalhos em marmore, nas edificaçóes modernas, acompanhapdo por este meio o successivo progresso d’este grande Estado do Pará,

$$
\text { Rua Padre Prudencio, } x_{3} \text { e } 15=\text { TELEPHONE } N^{\circ} 7
$$

Com Succursal em frente ao Cemiterio de Santa lzabel, N* 50, Telephone $N^{\circ} 15 a 1$

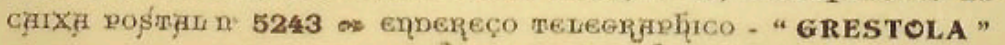

\section{$=B E L E M D P A R A=$}

\section{SALVADOR MESQUITA \& $\mathrm{C}^{a}$ CONSTRUCTORES}

Com Deposito dos seguintes materiaes :

Madeiras de todas as qualidades; mozaicos, azulejos, degráos e soleiras de pedra; cal em sacca, do reino e hydraulica, cimento telha typo Marselha (portugueza), dita commum e de vidro.

Tijollos, pias para corinha, lavatorios a bacias inglezas, desde a primeira qualidade até as mais inieriores, com todos os pertences.

Encanamento para agua e gaz; tanques de ferro e xinco ; ferragens, tintas, oleo e agua raz.

Figuras, balaustres e pinhas de louça; lambrequins de zinco, assim como estuques de cartăo em variedade para guarnecimento de forros, etc., etc.

BELEM-PARA 40 Travessa S. Francisco, $N^{\circ}$ 10 $\nsim$ BELEM-PARA

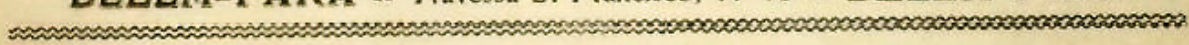

\section{FABRICACERAMICA}

Tubos de gré para encaualisação de todos os tamanhos, bacias para retrets, sifões, pinhas balahustre, figuras, potes, bilhas, moringos, talhas, cannos para fogão, vasos para jardim, tijollos parn dito; tijollos angolar, tijollos de alvenaria.

Este grande estabelecimeito do Norte tem passado por grandes reformas c achase apto a satisfazer qualquer encommenda com toda a promptidão e esmero. DEPOSITO - Rua de Santo Antonio canto da Travessa 15 de Agosto PRECOS SEM COMPETENGIA
Figuras 6, 7 e 8 - Anúncios dos jornais da época: Marmoaria Luzitana; Construtores Salvador Mesquitas \& $C^{a}$; Fábrica de Cerâmica. Fontes: Indicador Illustrado do Estado do Pará - Parte II (1910), Indicador Illustrado do Estado do Pará - Parte II (1910) e Folha do Norte, de 1898, respectivamente. 

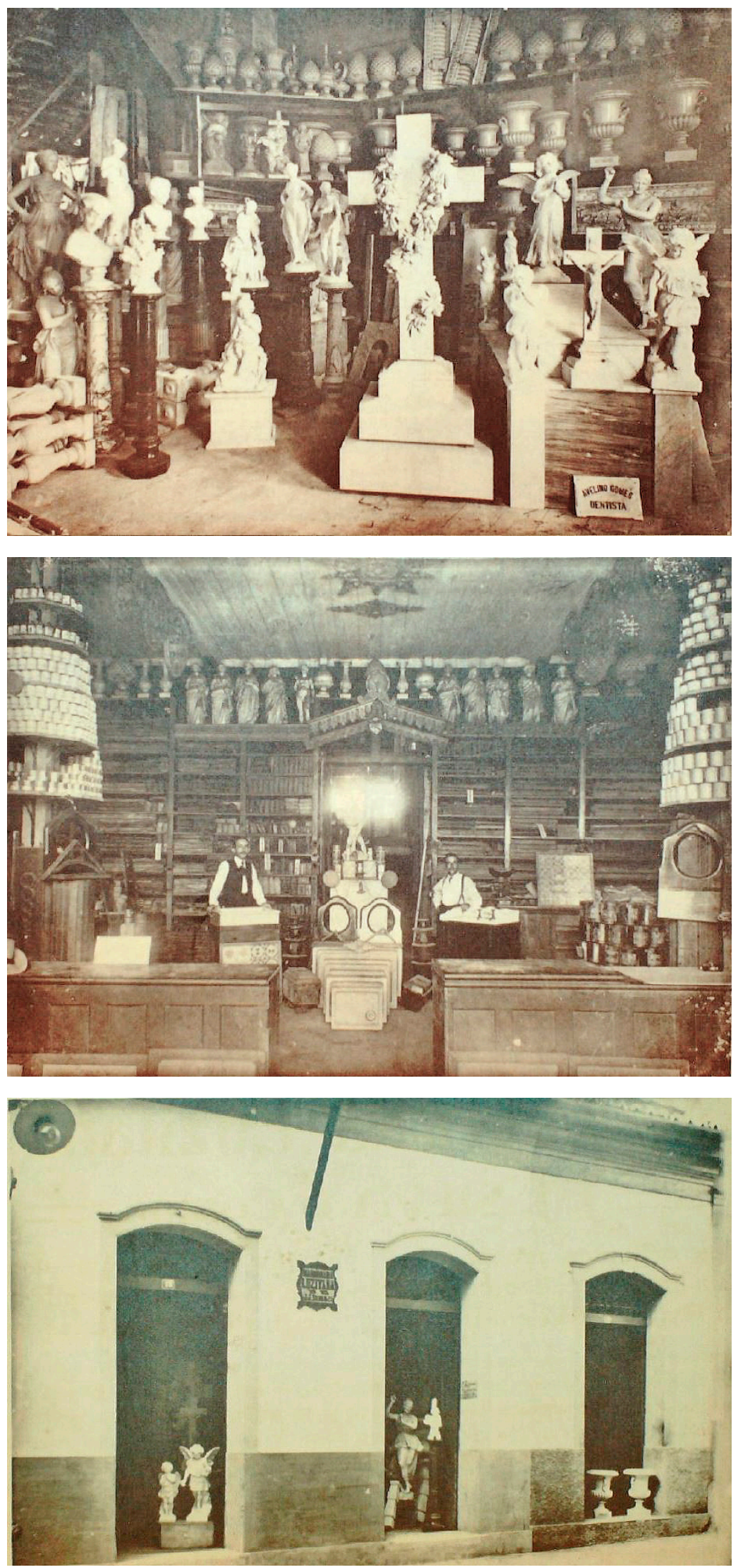

Figuras 9, 10 e 11: Fotos de lojas de materiais de construção que comercializavam ornamentos cerâmicos vitrificados em Belém: Grandes officinas mechanicas da "Marmoaria Luzitana", rua Padre Prudencio n ${ }^{\circ} 13$ e 15 com succursal em frente ao Cemiterio de Santa Izabel; Loja Salvador Mesquita, localizada na Travesa São Francisco; fachada externa da loja Marmoaria Luzitana. Fonte: Indicador Illustrado do Estado do Pará - Parte II (1910). 
22. Ver Ernesto Cruz (1971).

23. Ver Carmen Lúcia Valério Cal (1989).

24. Ver Thais Alessandra Bastos Caminha Sanjad (2007).

25. Ver Ana Maria Portela Domingues (2009).

26. Ver Cristiane Maria Magalhães (2014).

27. Ver Keli Cristina Scolari e Margarete Regina Freitas Gonçalves (2013). que era sóbrio e discreto. Também constava no relatório de 1905 que o uso desses ornamentos diminuiria com o tempo, mas isso não ocorreu, pelo contrário, tendo se intensificado à medida que surgiram novas edificações. ${ }^{22}$

As platibandas, na maioria das vezes, foram construídas posteriormente, não seguiam a concepção projetual anterior da edificação e tinham as mais diferentes inspirações de origem francesa, mulçumana, portuguesa ou mistura de estilos de diferentes origens. Essas podiam ser formadas por arcos ou colunas de estilo neoclássico, dos mais simples aos mais elaborados, podendo ser vazados ou maciços, com ou sem azulejos. ${ }^{23}$

Esses ornamentos de cerâmica vitrificada são exemplares importantes do patrimônio cultural de Belém e, por estarem expostos nas platibandas das edificações, estão mais vulneráveis à ação intempérica, cujas alterações nas peças se assemelham ao identificado por Thais Sanjad ${ }^{24}$ para a azulejaria, uma vez que apresentam composição semelhante e cujas ações dividem-se em físicas, químicas e biológicas. No entanto, podem ser também vitimadas por ação antrópica, inclusive atos de vandalismo.

A falta de conservação desses ornatos também está ligada à conservação do próprio edifício no qual ele está inserido. ${ }^{25}$ É necessário conhecer para compreender e caracterizar os tipos de alterações que os ornatos possuem como primeiro passo na conservação das peças e, posteriormente, encontrar técnicas de restauro específicas para o tratamento dos mesmos.

Em alguns casos, as peças são salvaguardadas e expostas como objetos museológicos. Contudo, fora do seu local de origem, as mesmas perdem a sua função, e a edificação a qual pertenciam perde sua unidade, como é o caso das esculturas em exposição no Sesc Boulevard (Figuras 12 a 15).

Em algumas cidades brasileiras, há a conscientização da importância dessa conservação como instrumento da memória da nossa história. Um exemplo é encontrado em São Paulo: um grupo privado que conserva o maior acervo existente de ornamentação cerâmica no Brasil, do final do seculo XVIII a início do XX, denominado de Instituto Portucale, com mais de 500 peças. Os ornamentos são mantidos e restaurados por profissionais do próprio instituto ${ }^{26} \mathrm{e}$ em Pelotas, por meio da restauração de ornamentos de decoração de fachadas que estão em processo de preservação pelo Instituto do Patrimônio Histórico e Artistico Nacional. ${ }^{27}$

O objetivo desta pesquisa é identificar os padrões de ornamentos de platibanda que compõem a arquitetura da parte mais antiga (centro histórico e entorno) de Belém e que, como vimos, se integraram intensamente à arquitetura da cidade, de modo a traçar subsídios para a sua preservação. 


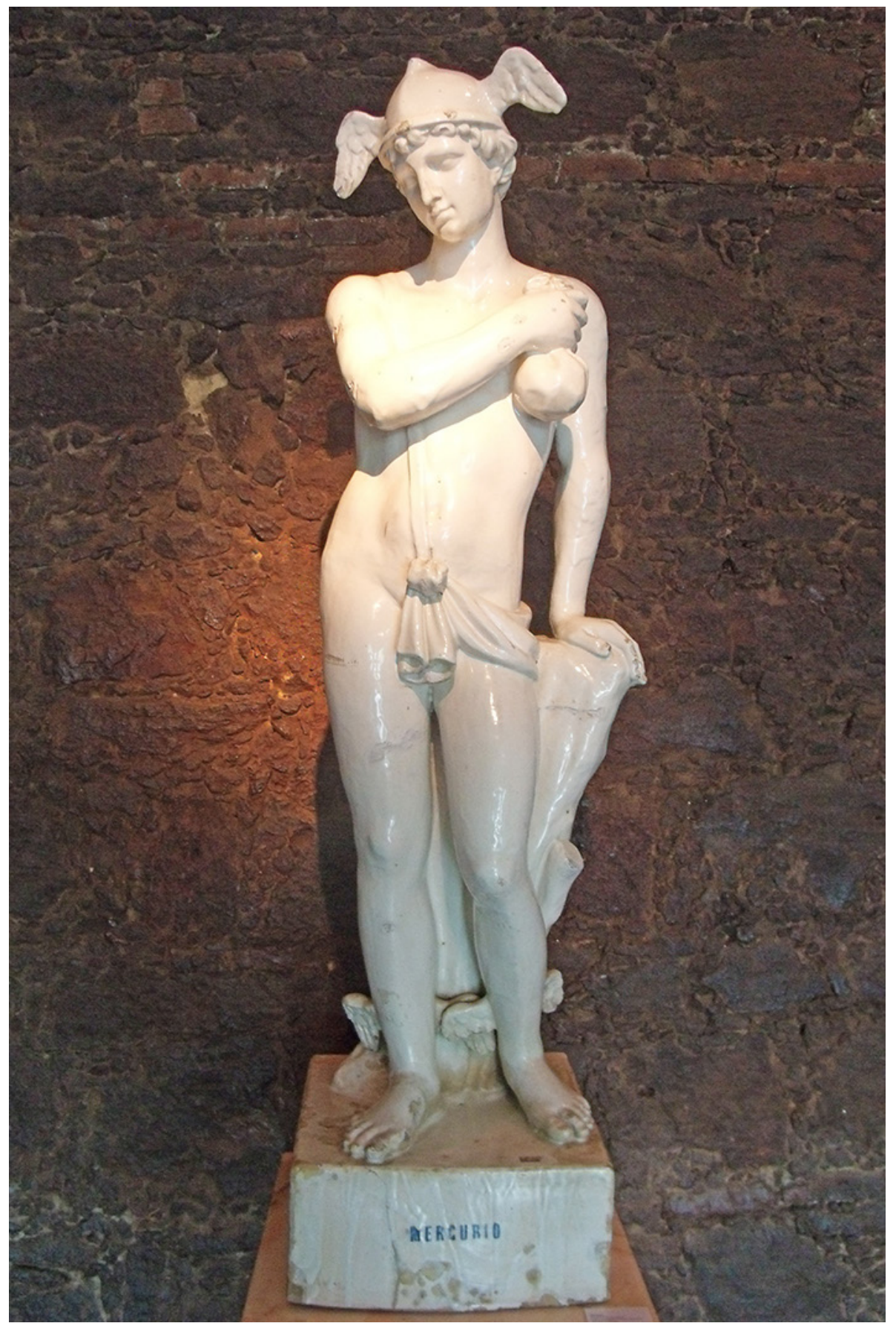

Figuras 12, 13, 14 e 15: Esculturas expostas no Sesc Boulevard, Belém, cuja identificação e fábrica são: Mercurio, Fábrica Sto. Antonio Porto; Commercio, Fábrica Devesas; Commercio, Fábrica Devesas José Pereira Valente; sem identificação, fábrica desconhecida. Fotografias de Tainá Arruda, 2015. 


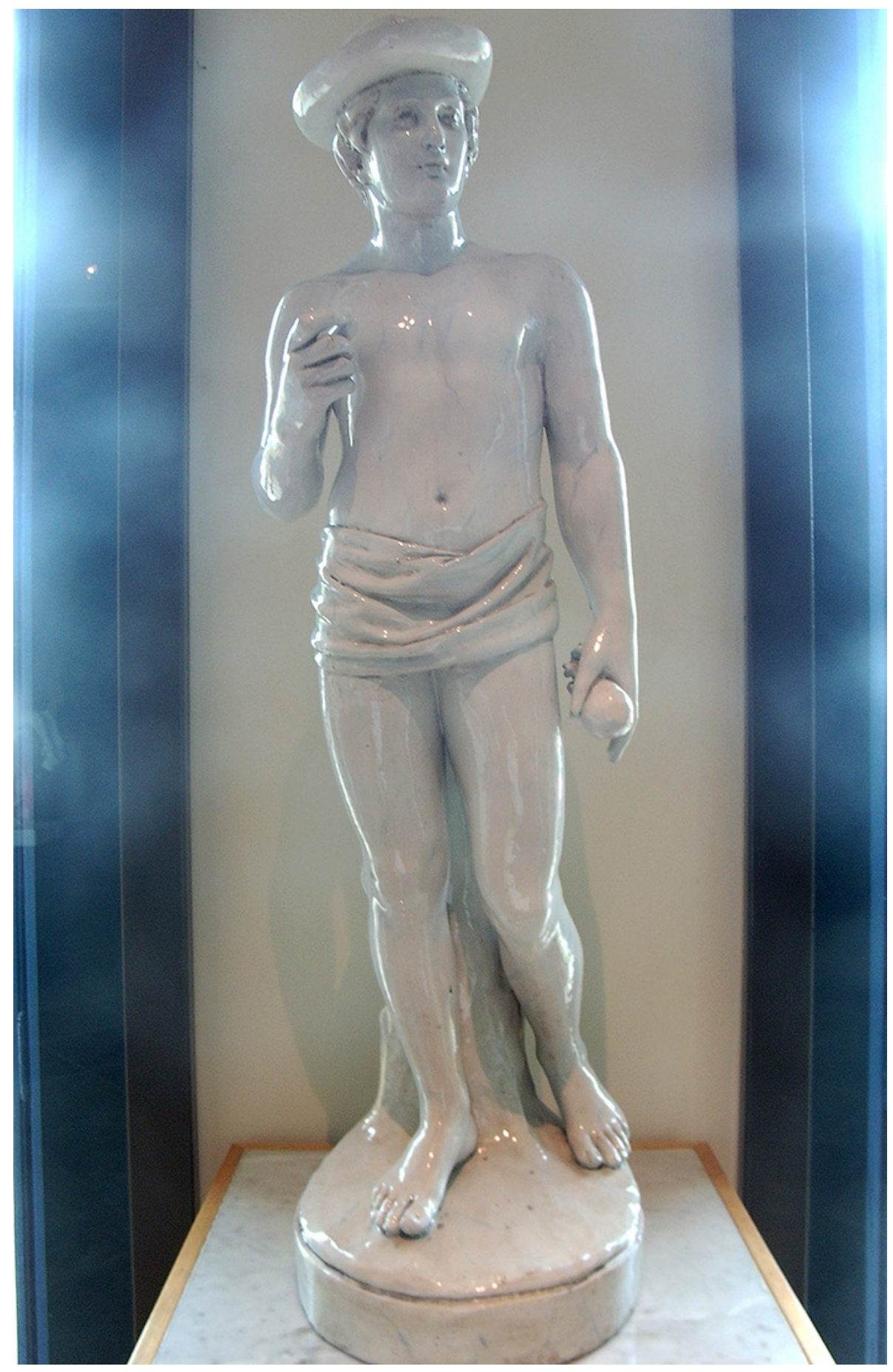

Figura 13 


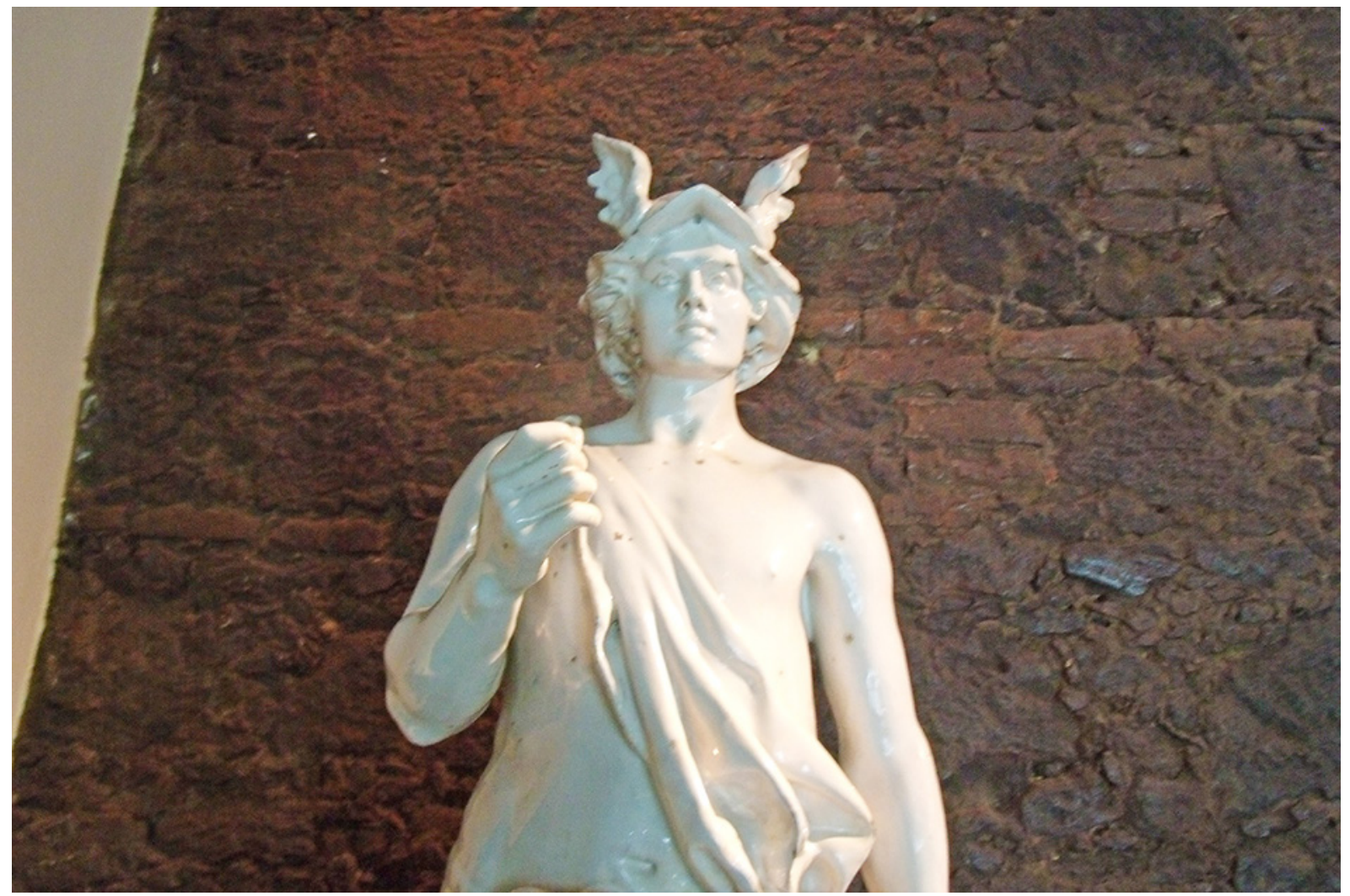

Figura 14

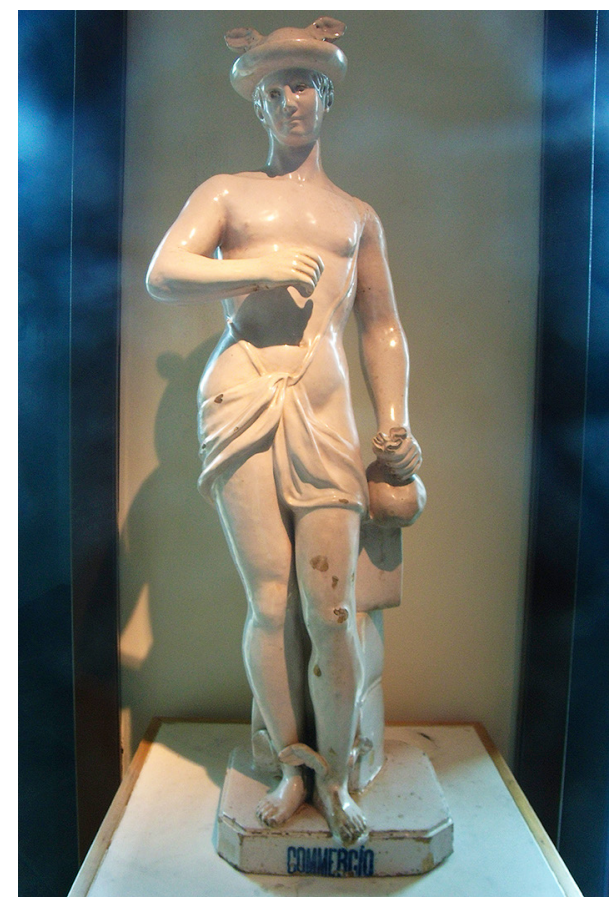

Figura 15 
A área do Centro Histórico de Belém e seu entorno corresponde aos bairros da Cidade Velha, Reduto, Campina e partes dos bairros de Nazaré e Batista Campos, de acordo com a Lei Municipal n 7.709, de 18 de maio de 1994 (Figura 16).

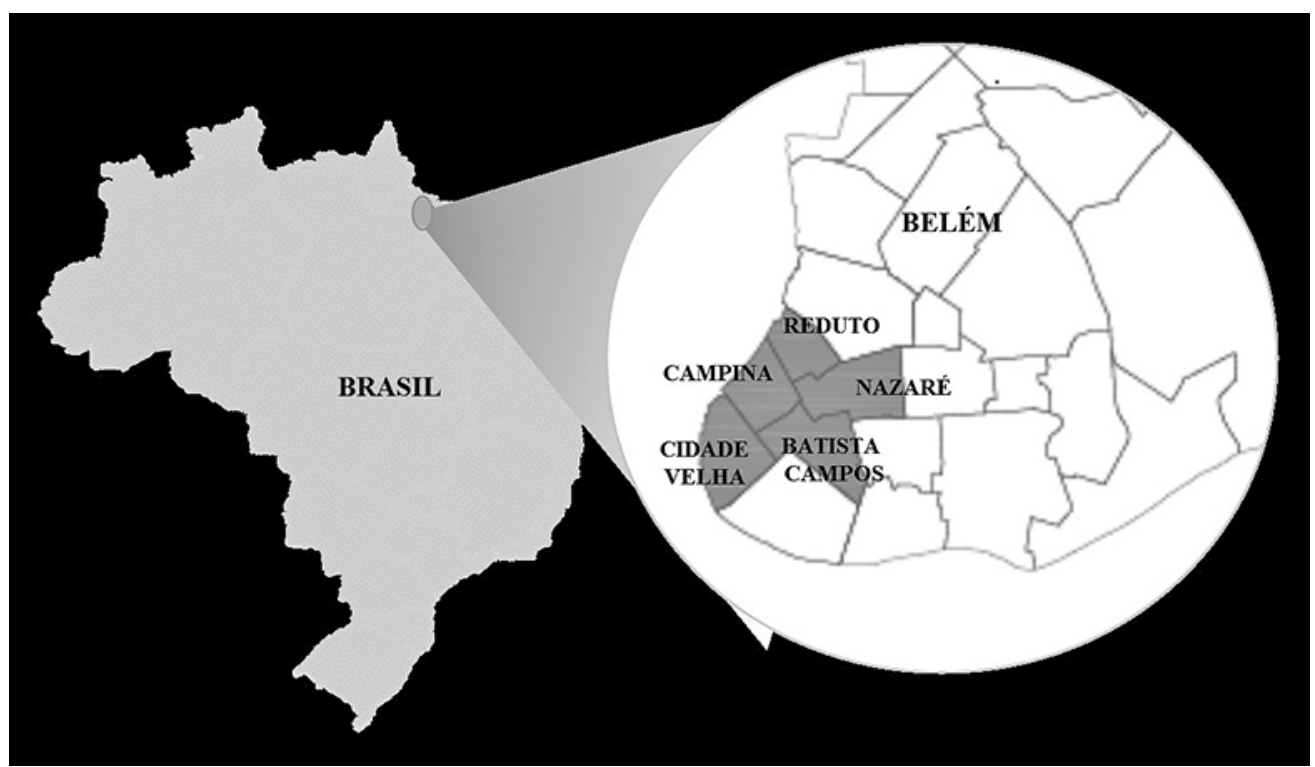

Figura 16 - Mapa do Centro Histórico de Belém e seu entorno, com a indicação dos bairros que o constituem (Nazaré, Batista Campos, Campina, Cidade Velha, parte do Reduto e do Jurunas).

\section{ABORDAGEM METODOLÓGICA}

O inventário foi a ferramenta usada para identificar a localização e os tipos dos ornamentos existentes na área de estudo, os quais foram organizados em fichas cadastrais, cujos campos de preenchimento são: endereço da edificação; presença de inscrição da fábrica na peça; fotos com descrição individual; tipologia do ornamento (pinha, globo, estátua, busto, balaústre); estado de conservação dos ornamentos (bom, ruim, péssimo ou lacuna); estado de conservação do imóvel (bom, precário, em arruinamento, arruinado); localização (imagem do bairro e a marcação do lote em que o ornamento se encontra); autora da ficha; data do levantamento; e a orientadora da pesquisa (Figura 17).

Por se tratar dos elementos situados no coroamento das edificações, nem sempre foi possivel observar de perto todas as coberturas para melhor detalhamento e descrição dos dados coletados. Foram encontrados, em alguns 

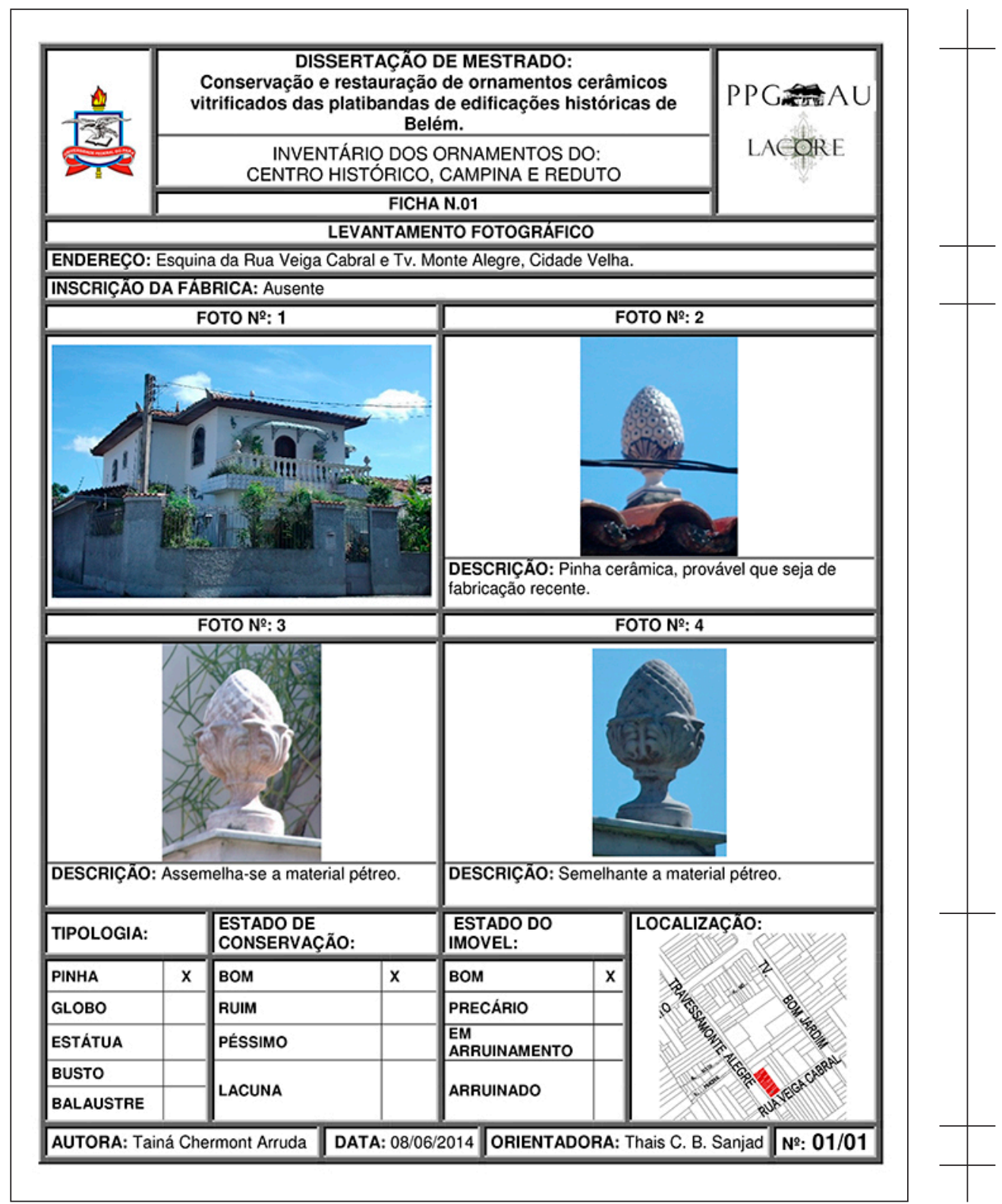

Cabeçalho

Endereço e identificação da fábrica

Fotos gerais da edificação e de seus ornamentos

Informações sobre a tipologia, estado de conservação do ornato e do imóvel

Autora, data do levantamento fotográfico, orientadora e número de fichas referentes ao imóvel

Figura 17 - Modelo de ficha utilizada no inventário.

casos, os ornamentos de cerâmica vitrificada recobertos com uma camada de tinta, o que permite confundi-los com os ornamentos em argamassa pintada. Dessa maneira, optou-se por registrar todos (cerâmica vitrificada, cantaria e argamassado com pintura) de modo a ter-se a informação acerca da variedade tipológica formal, com possibilidade de fazer-se a identificação de materiais futuramente, uma vez que o risco de desaparecimento dessas peças é elevado. 
28. Ver Gilson Luiz Volpato (2015).
A pesquisa segue a linha descritiva, que, segundo Volpato, ${ }^{28}$ descreve cada uma das variáveis, sendo que uma não está relacionada às demais, por serem independentes. Os tipos de deterioração nos ornamentos são variáveis independentes e dependentes ao mesmo tempo; isso ocorre pois nem sempre um tipo de deterioração reage em um ornamento da mesma forma como age no outro, algo apenas compreensivel em se considerando as condições particulares de cada peça.

As variáveis observadas são: área com maior concentração de ocorrências; tipos de ornamentos mais frequentes nas edificações; ornamentos desaparecidos e principais alterações nas edificações. Os desenhos gerados foram divididos por bairro com o objetivo de melhorar a visibilidade dos lotes em quadra.

Os resultados foram tratados em gráficos com intuito de auxiliar na sua discussão. A legenda adotada considerou ícones das tipologias mais encontradas com base no levantamento realizado, que correspondem a: estátua, base, balaústre, busto, pinha, pináculo, vaso e globo (Figura 18).

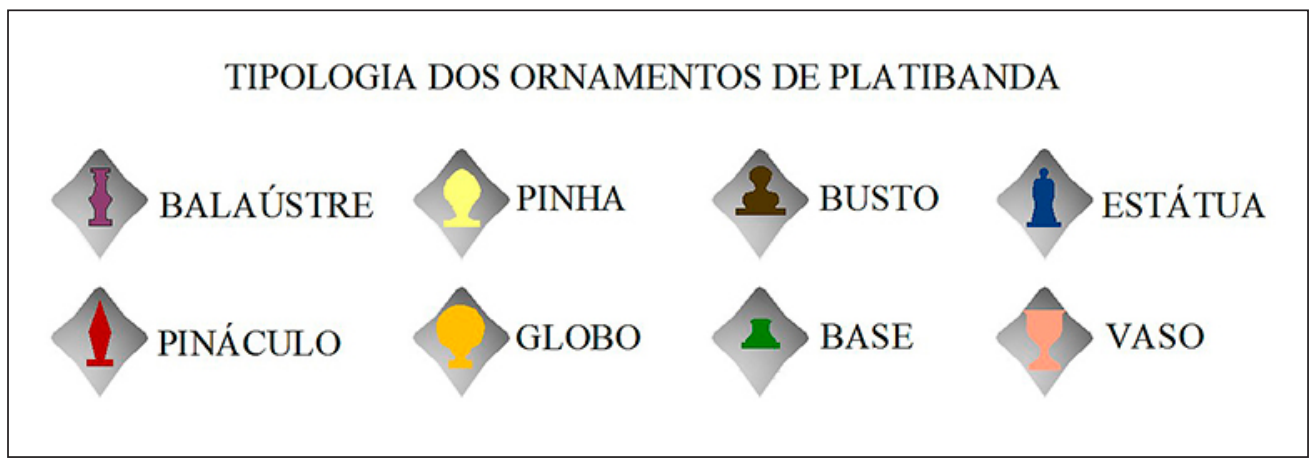

Figura 18 - Legenda aplicada à identificação dos ornatos de platibanda.

\section{PADRÕES IDENTIFICADOS DE ORNAMENTOS DE PLATIBANDA}

Com base no conhecimento da tecnologia da conservação e restauro, foi possível compreender durante o inventário que os exemplares in loco estão cada vez mais escassos devido à falta de preservação, ao avançado grau de deterioração em que se encontram e ao furto dos mesmos para serem vendidos como antiguidades aos colecionadores particulares.

Entre os tipos de ornamentos existentes em Belém do Pará foram identificados vasos, pinhas, balaústres, estátuas, pináculos, bustos e globos. Esses ornamentos seguem representações de padrão neoclássico, o qual foi inteirado em edificações de estilo eclético após o século XIX na cidade de Belém. 
Observa-se que existem ornatos que se diferenciam na cor e podem ser monocromáticos, policromáticos e marmoreados. $\bigcirc$ Catálogo da fábrica de cerâmica e fundição das Devesas, de 1910,29 confirma essas variedades quando cita a variação de valores que as peças atingem ao serem feitas em fosco, que significa branco ou vermelho, diferindo-se se são bronzeadas, a caráter ou matizadas nas variadas cores; também há a possibilidade de serem pintadas a óleo para fingir mármore ou granito.

A tipologia mais encontrada no Centro Histórico e seu entorno são os balaústres, que correspondem a $63 \%$ do geral. Essa tipologia foi amplamente usada no coroamento de edificações do século XIX. As pinhas ou pinhões e os globos existem em frequência aproximada de 10\% de todas as tipologias; segue a estes os pináculos e as bases, as quais são vestígios de ornamentos, com a porcentagem de $6 \%$. $\bigcirc$ uso de estátuas corresponde a $2 \%$ do total, e a de bustos e outras tipologias equivale a $1 \%$ cada (Tabela 1).

Na tipologia de vaso foram identificadas dezessete variedades de forma, com presença ou ausência de coroamento com haste, e diversos motivos ornamentais, geralmente florais com fita ou laçaria, além de imagens grotescas, como exemplo as bestas ou feras, que são formas de figuras e objetos imaginários (Figura 19).

Outra tipologia identificada diz respeito às pinhas (ou pinhões), que têm esse nome por representar o fruto do pinheiro. Foram identificados onze padrões com formas variadas. A pintura pode ser monocromática, geralmente com relevos em azul sob fundo branco, ou policromática, predominando o azul e amarelo, sendo as peças bastante coloridas mais raras. Foram encontrados ainda exemplares, menos frequentes, com pintura imitando mármore (marmorizado), com veios em tons cinza ou lilás. Os motivos decorativos em relevo também são bastante diversificados, com predominância da utilização de lóbulos, estrelas e elementos fitomórficos, como flores e folhas de acanto (Figura 20).

Foram identificadas vinte e uma variações do padrão globo (ou esférico). Essa tipologia tem como forma principal a esfera, e quando apresenta elementos na parte superior fica semelhante a uma compoteira ou pote com tampa, encimado geralmente por pináculos ou variações esféricas de pequena dimensão. Os motivos decorativos geralmente são elementos fitomórficos, principalmente flores e folhas de acanto, apresentando ainda estrelas e lóbulos. No Catálogo da fábrica de cerâmica e fundição das Devesas é possível observar essa variação de características decorativas em globos: com cabeças de carneiro, de folhas e lisas (Figuras 21 a 23). 
Tabela 1: Relação entre a quantidade de tipologias presentes em cada bairro que constitui o Centro Histórico e seu entorno.

\begin{tabular}{|c|c|c|c|c|c|c|c|}
\hline FOTO & ORNAMENTO & $\begin{array}{l}\text { BATISTA } \\
\text { CAMPOS }\end{array}$ & $\begin{array}{l}\text { CIDADE } \\
\text { VELHA }\end{array}$ & CAMPINA & REDUTO & NAZARÉ & GERAL \\
\hline & BALAUSTRE & 0 & 33 & 103 & 21 & 0 & 157 \\
\hline & GLOBO & 2 & 1 & 18 & 5 & 0 & 26 \\
\hline & $\mathrm{PINHA}$ & 1 & 10 & 10 & 6 & 0 & 27 \\
\hline & ESTÁTUA & 0 & 1 & 4 & 1 & 0 & 6 \\
\hline & BUSTO & 1 & 0 & 2 & 0 & 0 & 3 \\
\hline & PINÁCULO & 1 & 0 & 7 & 7 & 1 & 16 \\
\hline & BASE & 0 & 2 & 6 & 6 & 0 & 14 \\
\hline & TOTAL & 5 & 47 & 150 & 46 & 1 & 247 \\
\hline
\end{tabular}



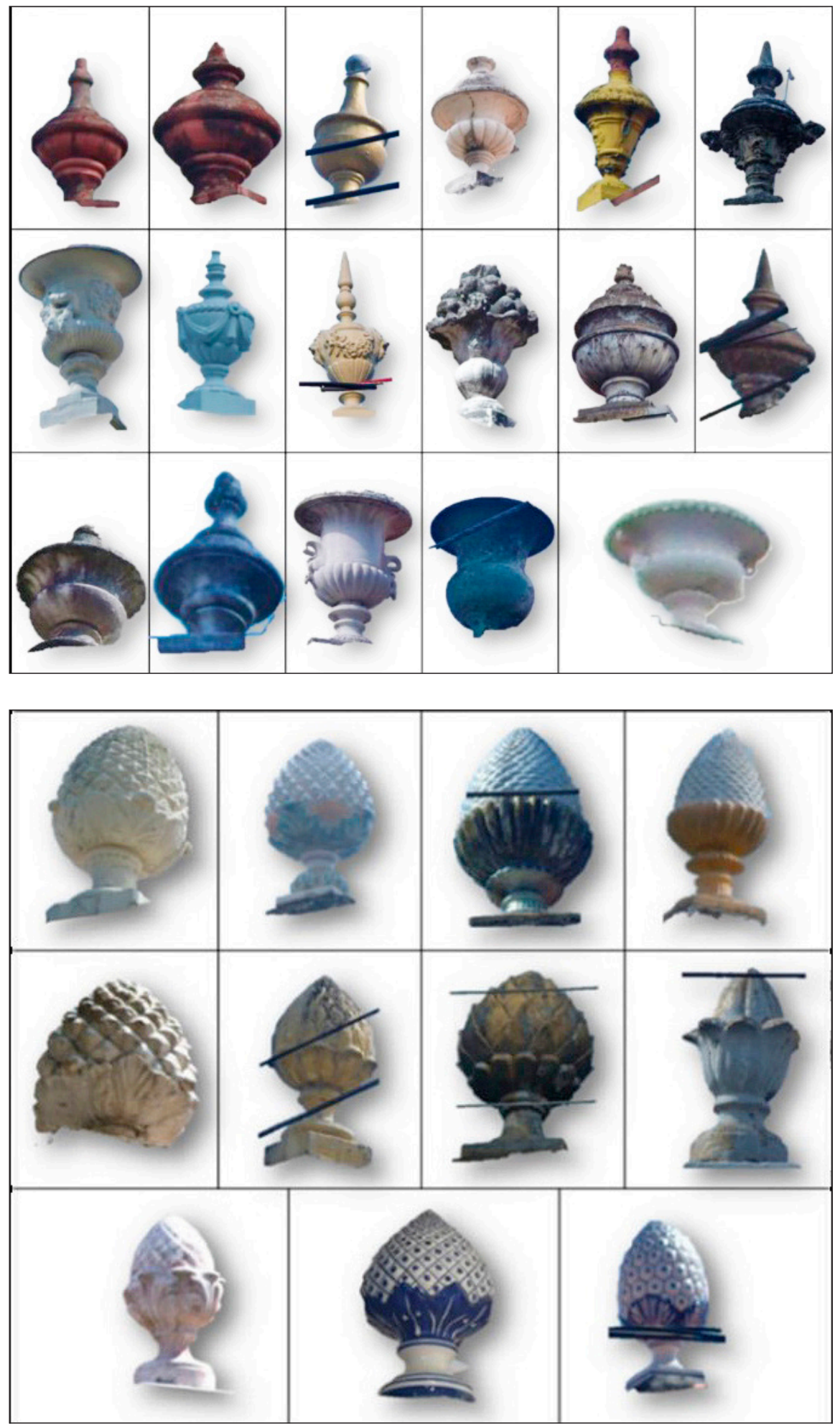

Figura 19 - Variedade de ornamentos da tipologia "vaso" do Centro Histórico da cidade de Belém do Pará e seu entorno.

Figura 20 - Variedade de padrões de pinhas do Centro Histórico da cidade de Belém do Pará e seu entorno. 

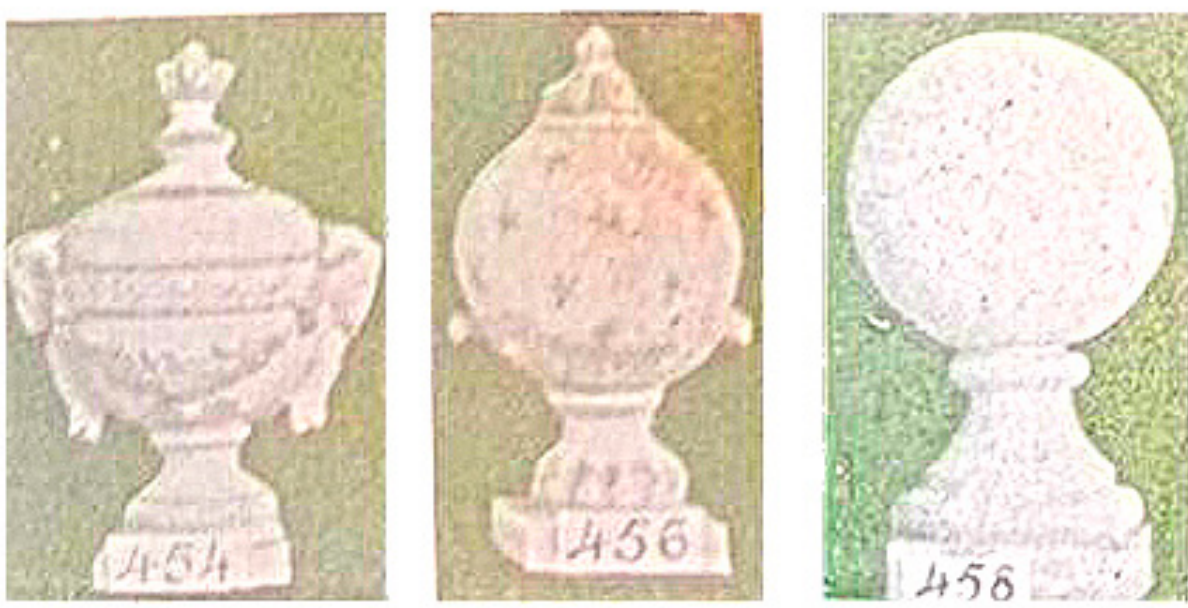

Figuras 21, 22 e 23 - Imagens dos globos disponíveis no Catálogo da fábrica de cerâmica e fundição das Devesas, seguindo as seguintes denominações: com cabeça de carneiro; de folhas; lisas. Fonte: Catálogo da fábrica de cerâmica e fundição das Devesas - Antonio Almeida da Costa \& Cia.. Vila Nova de Gaya (1910).

Um exemplar apresenta pintura policromática, enquanto os demais estão com camada de pintura aplicada sobre o vidrado ou correspondem a ornamentos argamassados pintados (Figura 24).

$\bigcirc$ padrão balaústre apresenta 15 variedades identificadas. A composição envolve os seguintes elementos: corrimão ou travessa, capitel, colarinho e fuste, que é dividido em colo, parte superior e pança, parte inferior e base. Esse ornamento, em forma de pequena coluna, é disposto de maneira regular na platibanda, com espaçamento fixo. Geralmente tem forma torneada e a mais recorrente é a que a parte inferior do fuste é mais robusta que a superior, ou seja, a medida do colo, que é a concavidade na região superior, é menor que a medida da pança, forma como é denominada a convexidade na porção inferior da peça.

No Catálogo da fábrica de cerâmica e fundição das Devesas, de 1910,30 os balaústres têm como variação serem: quadrado com ornado, liso e liso com faixa ou redondo liso e ornado.

Os motivos decorativos são geralmente constituídos de lóbulos e elementos fitomórficos, porém, podem ser também lisos ou canelados. A maioria dos balaústres possui escapo, que corresponde a filetes na parte superior separando o capitel e a base, e também tem escócias, que são dois filetes ou toros usados na base (Figura 25). 

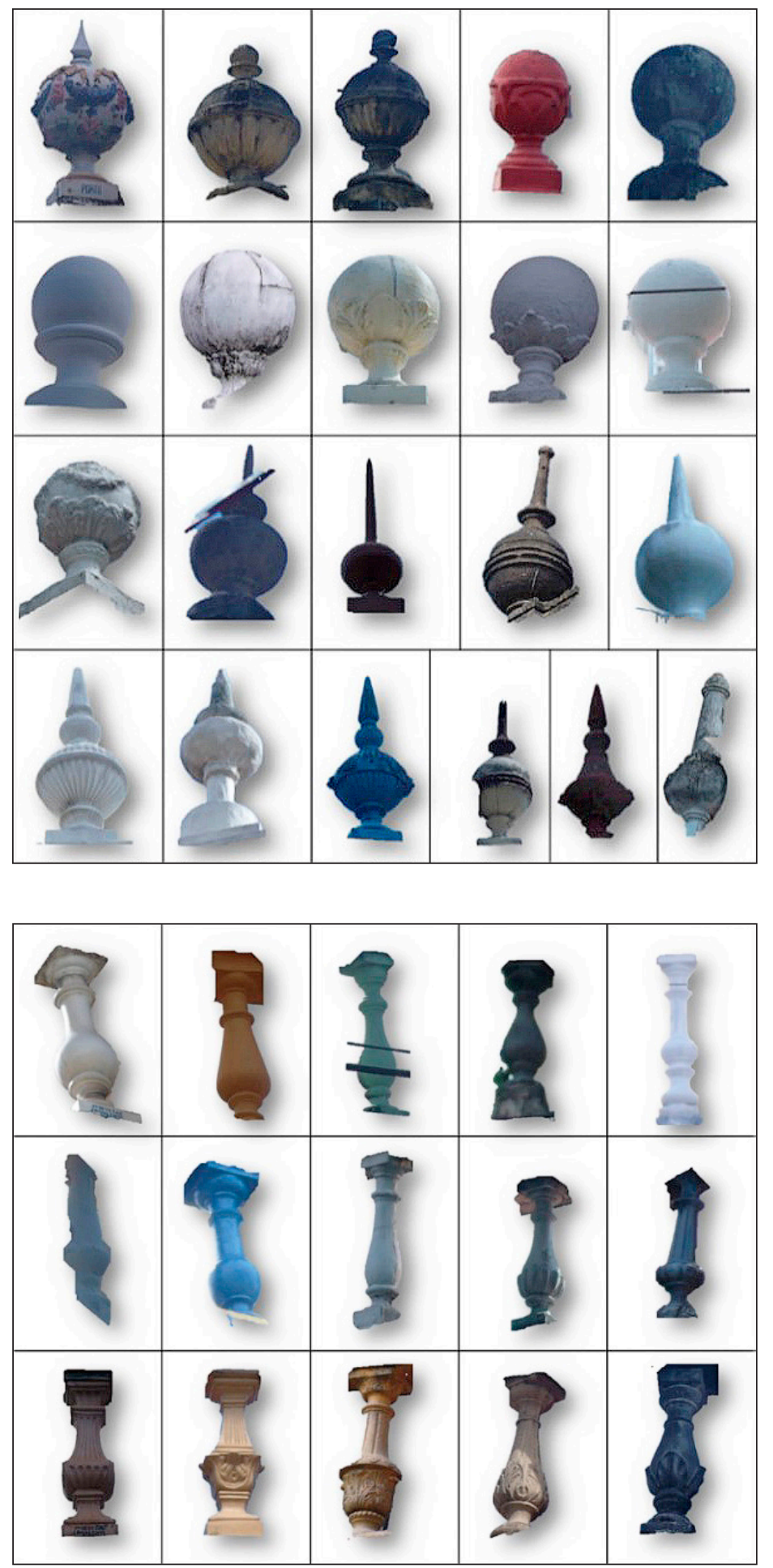

Figura 24: Variedade do padrão globo do Centro Histórico de Belém do Pará e seu entorno.

Figura 25: Variedade do padrão de balaústre do Centro Histórico de Belém do Pará e seu entorno. 
31. Ver Catálogo... (1910).

32. Ver Catálogo... (1910).
Também se encontra disponível no Catálogo da fábrica de cerâmica e fundição das Devesas modelos de bustos, representando Cristo, Magdalena, os reis de Portugal D. Carlos I, D. Luís I e D. Pedro V, Camões, Castilho, Garret, Alexandre Herculano, Bocage, Vasco da Gama, Marquês de Pombal, Rosa e Conde Ferreira. Nota-se que as feições seguem características neoclássicas (Figuras 26 a 28).

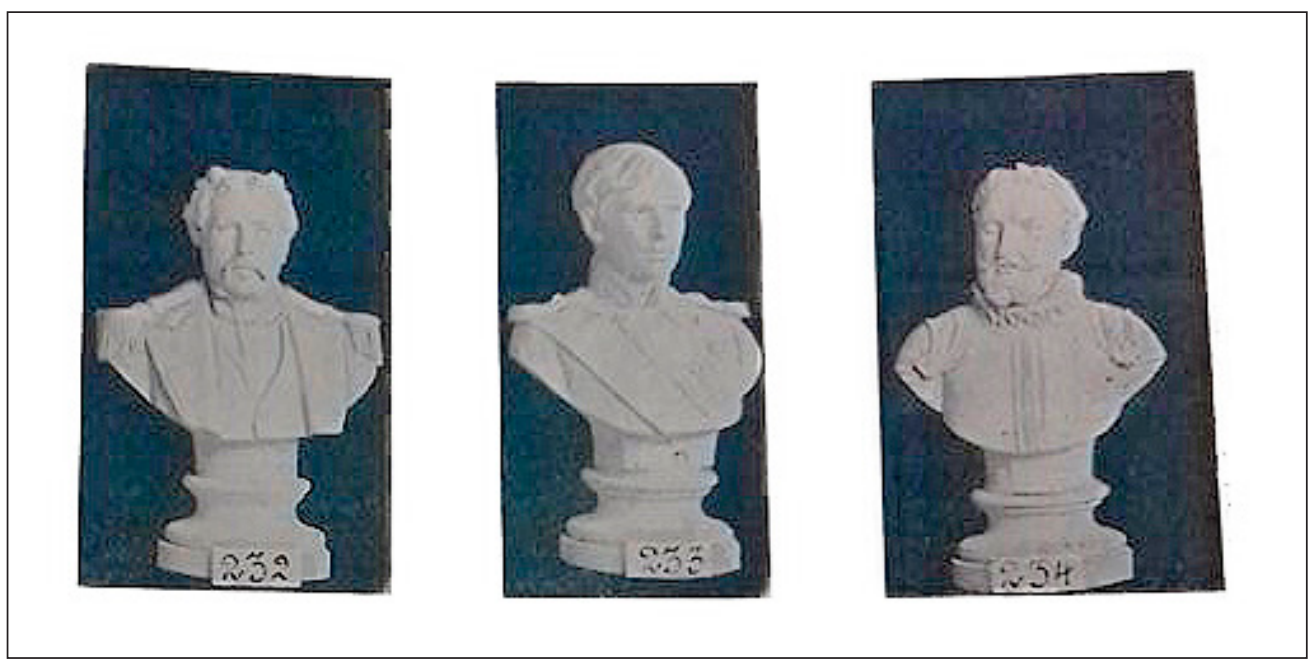

Figuras 26, 27 e 28 - D. Luís I; D. Pedro V; Camões. Fonte: Catálogo da fábrica de cerâmica e fundição das Devesas - Antonio Almeida da Costa \& Cia.. Vila Nova de Gaya (1910).

Na área em que o inventário foi realizado, foram encontrados apenas dois padrões de bustos (Figura 29). Eles confirmam os moldes dos modelos neoclássicos seguidos, por possuírem feições joviais e características de modelos do império romano, a exemplo dos cabelos encaracolados e do capacete militar com folhagem de acanto.

Ornamentos com forma cônica, octogonal ou denominados de "pyramides", segundo o Catálogo da fábrica de cerâmica e fundição das Devesas, ${ }^{31}$ foram identificados com dezessete variedades de padrões e são chamados de pináculos ou coruchéus e variam em dimensão e nas formas, que podem ser geométricas com quinas ou boleadas (Figura 30).

As estátuas formam a tipologia que se encontra em maior variedade no Catálogo da fábrica de cerâmica e fundição das Devesas, ${ }^{32}$ contendo 228 modelos diferentes. Os padrões de estatuária encontrados no Centro Histórico de Belém e seu entorno apresentam quinze variedades, as quais seguem padrões neoclássicos, com feições juvenis. Entre as esculturas masculinas observa-se que a grande maioria tem vestimenta, como a toga ou o uniforme militar, e uma única 


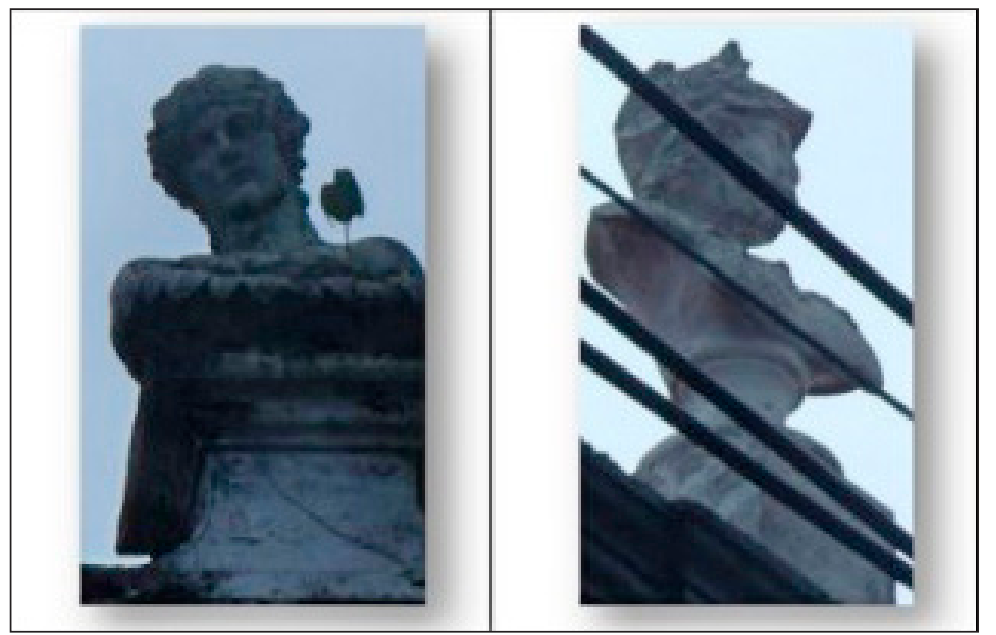

Figura 29 - Variedade de padrão de busto no Centro Histórico de Belém do Pará e seu entorno.

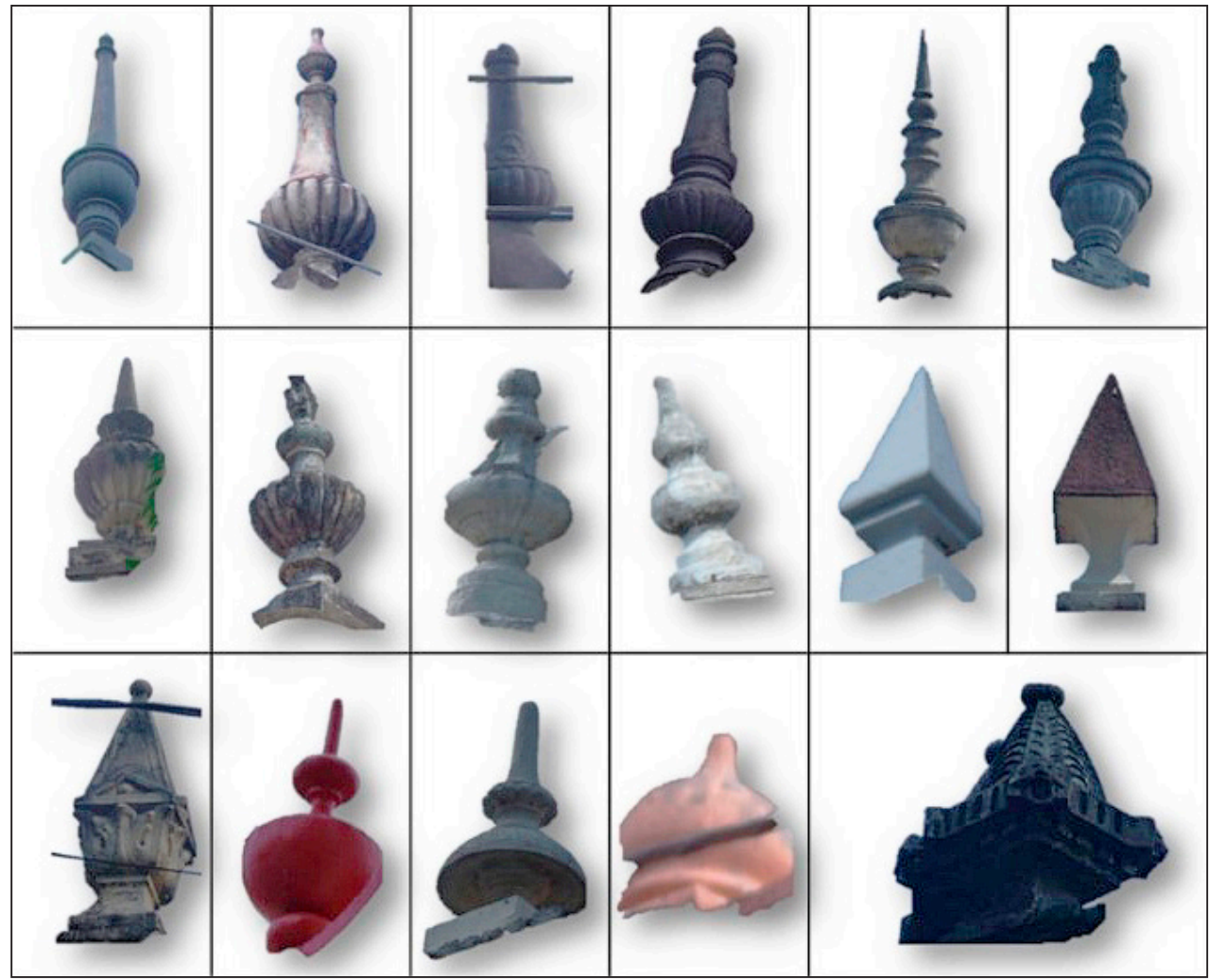

Figura 30 -Variedade de padrões de pináculos do Centro Histórico de Belém do Pará e seu entorno. 
está despida, com proporções perfeitas segundo modelos clássicos, com grande atenção à musculatura humana. No caso das esculturas femininas, a vestimenta se assemelha à utilizada para a caracterização de divindades (Figura 31 ).

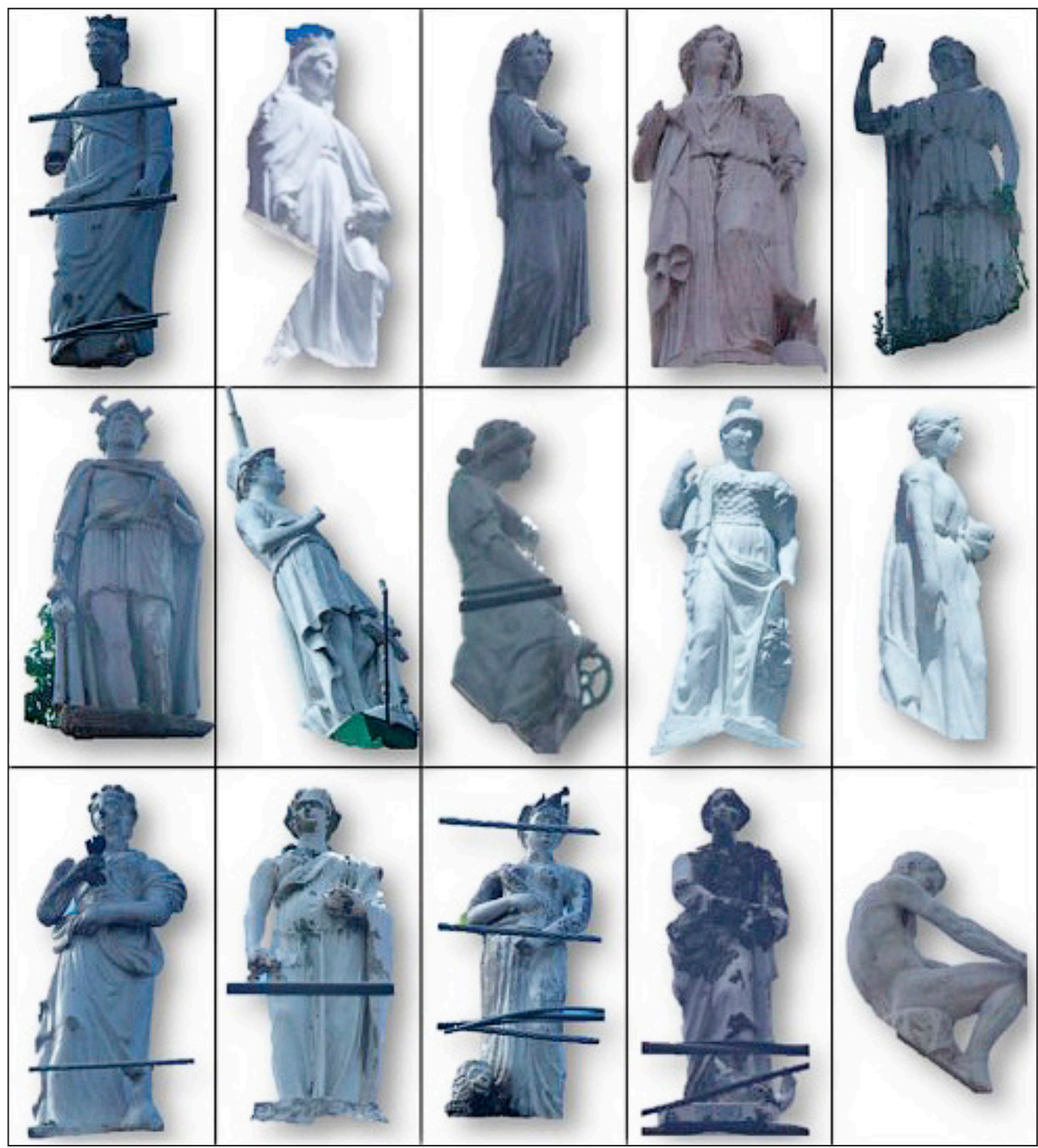

Figura 31 - Variedade de padrões de estátuas do Centro Histórico de Belém do Pará e seu entorno. 
Esses padrões de ornamentos foram muito utilizados em outras cidades brasileiras e, dentre as peças com inscrição de fabricante, observou-se a presença marcante na área do Centro Histórico e seu entorno daquelas provenientes da Fábrica Cerâmica e de Fundição das Devesas, localizada na região do Porto, e cujo catálogo confirma a disponibilidade desses ornamentos entre os produtos feitos pela fábrica (Figura 32).

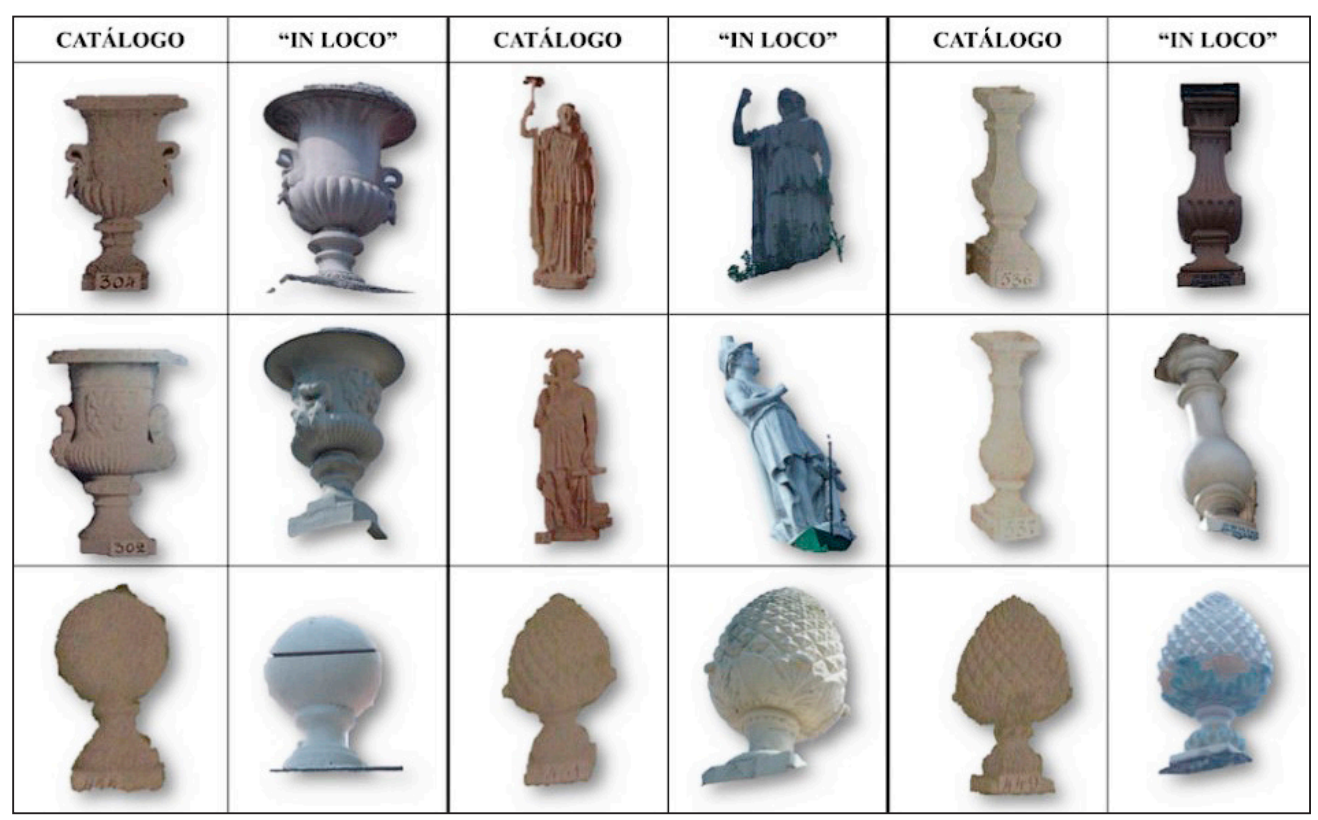

Figura 32 - Ornamentos de platibanda de edificações de Belém e seu padrão correspondente no catálogo da Fábrica de Cerâmica e de Fundição das Devesas. Fonte: Elaborada pela autora, 2016, incluindo imagens de Catálogo da fábrica de cerâmica e fundição das Devesas - Antonio Almeida da Costa \& Cia.. Vila Nova de Gaya (1910).

\section{PRESENÇA DE ORNAMENTOS POR BAIRRO DO CENTRO HISTÓRICO E ENTORNO}

Otatal de edificações inventariadas corresponde a duzentos e vinte e cinco imóveis localizados no Centro Histórico de Belém e seu entorno, cujo perímetro compreende cinco bairros. A maior parte das edificações com ornatos está localizada na Campina, seguida dos bairros do Reduto, Cidade Velha, Batista Campos e Nazaré (Figura 33).

A maior concentração de ornamentos de platibanda no bairro da Campina está relacionada às expansão do bairro no século XIX e à importância 
33. Ver Nestor Goulart Reis Filho (2004).

34. Ver Augusto Meira Filho (2015). que o mesmo desempenhava então, com reflexo direto na aparência das edificações conforme o gosto da época.

\section{QUANTIDADE DE EDIFICAÇÕES COM ORNAMENTOS DE PLATIBANDA POR BAIRRO NO CENTRO HISTÓRICO E SEU ENTORNO}

$1,78 \%$

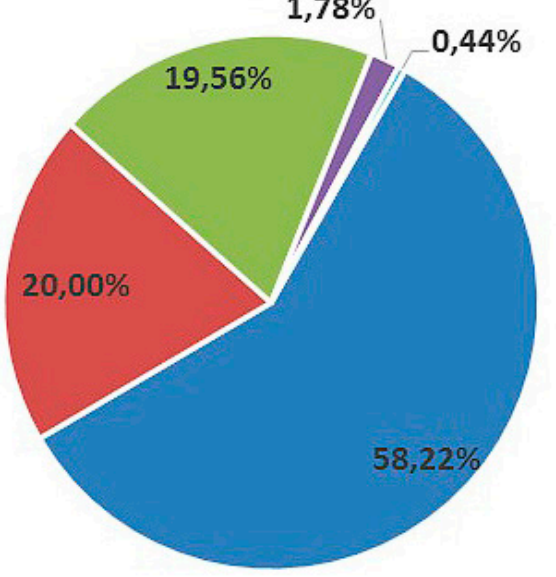

Campina

Reduto

Cidade Velha

Batista Campos

Nazaré

Figura 33 - Gráfico da distribuição de edificações com ornamentos de platibanda no Centro Histórico de Belém e seu entorno.

O inventário indica uma concentração maior nas proximidades da orla da baía de Guajará, ou seja, nas partes mais antigas do bairro, e vai diminuindo à medida que avança para o interior da cidade, ou seja, no sentido da expansão urbana (Figura 34).

Na segunda metade do século XVII, impulsionada pelo comércio das drogas do sertão, denominação dada a produtos como cacau, cravo, guaraná, urucum, poaia, baunilha, gordura do peixe-boi, ovos de tartaruga, castanhas, ervas com propriedades curativas, fibras e tinturas, Belém ganha destaque em relação ao restante da América Portuguesa e com isso passa por um processo de adensamento populacional e desenvolvimento urbano. As construções começam a ser executadas de pedra e barro. ${ }^{33}$

No século XVIII, com a circulação monetária e o mercado ligado ao comércio internacional, Belém torna-se o centro comercial e político, permitindo alterações urbanas e construtivas nas edificações públicas, as quais seguem traços neoclássicos, sendo o primeiro local no Brasil a usá-los, ${ }^{34}$ e também religiosas imponentes realizadas com matéria-prima mais refinada. 


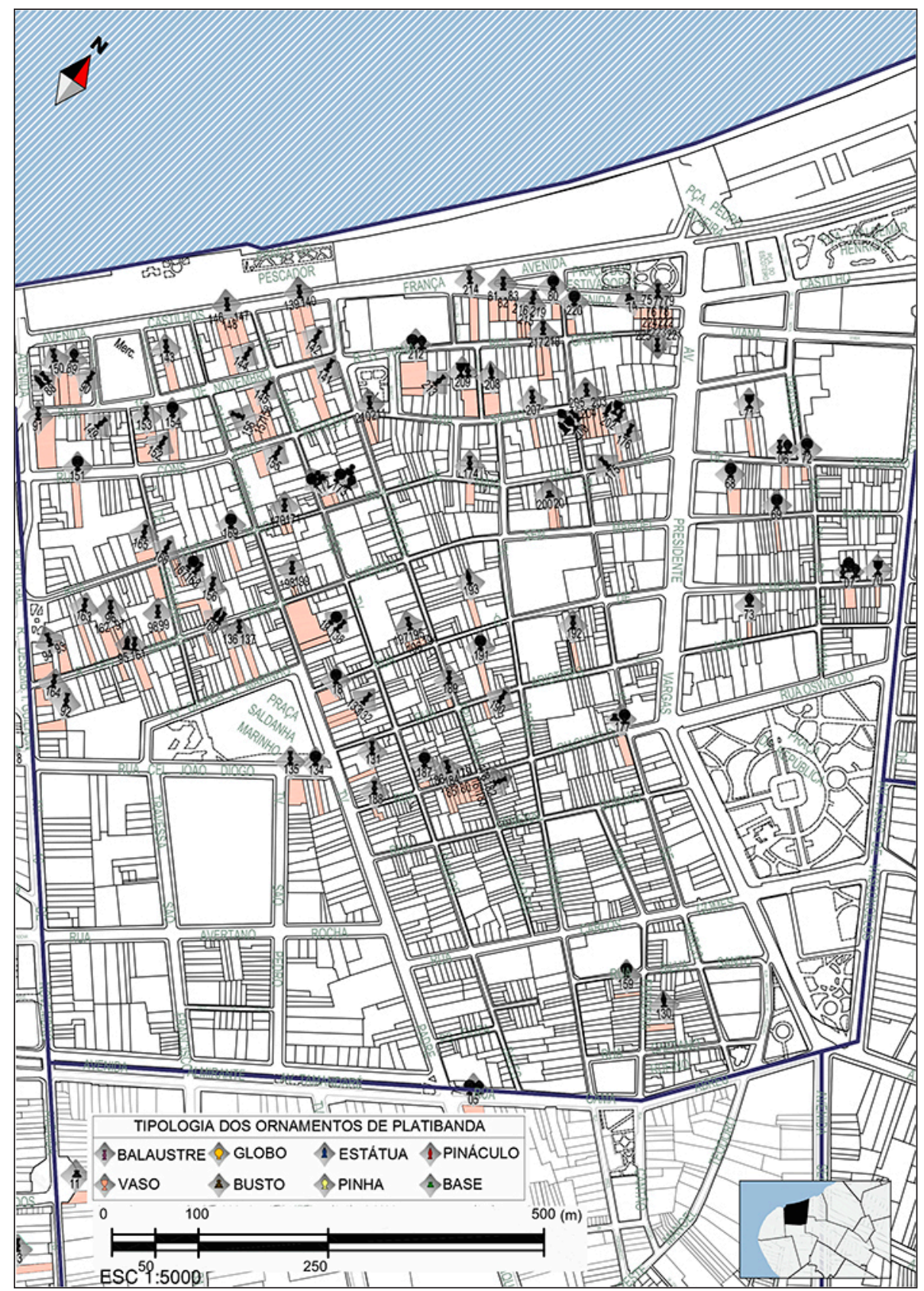

Figura 34 - Edificações com ornamentos de cerâmica vitrificada em platibanda no bairro da Campina.

A Campina foi o novo centro da cidade durante o século XIX, quando era o polo comercial e social de Belém. Esse momento foi marcado por melhoramentos urbanos e de intensa ocupação no bairro, patrocinados pelas riquezas geradas 
35. Ver Augusto Meira Filho (2015).

36. Ver Leis... (1905)

37. Ver Nestor Goulart Reis Filho (2004).

38. Ver Nestor Goulart Reis Filho (2004). pela economia da borracha. A proximidade com o porto dava à rua dos Mercadores, atual rua João Alfredo e Santo Antônio, destaque por seu grande fluxo de produtos e local de encontro da vida social, enquanto a XV de Novembro era o centro financeiro. ${ }^{35} \bigcirc$ intenso movimento portuário permitiu que a cidade mantivesse os altos padrões de progresso até a década de 1920.

Foi notável a sofisticação das fachadas das edificações dessa região nesse período, dado o uso de materiais importados. As características ecléticas foram adicionadas a várias das edificações barrocas e neoclássicas já existentes, dado à necessidade de a burguesia ostentar a riqueza e erudição arquitetônica. Nesse contexto, e atentos ao cumprimento do Código de Postura vigente na cidade de Belém na gestão do intendente Antônio Lemos, os proprietários das edificações precisaram construir edificações com platibanda, ou mesmo adaptar as antigas eliminando os beiras. ${ }^{36}$ Cada vez mais presente nas construções, as platibandas começaram a ser adornadas com os mais variados estilos de ornamentos.

A implantação das residências no lote no século XIX não se diferia muito em relação ao que se praticava no anterior, seguindo padrão que Nestor Goulart Reis indica como recorrente no país. ${ }^{37}$ Paulatinamente foram sendo realizadas modificações na face externa das edificações, por meio do aperfeiçoamento de detalhes construtivos, bem como no isolamento progressivo das edificações mais ricas. Em relação às platibandas, nas edificações já existentes, implantavam-nas na fachada e os beirais continuavam nas faces laterais, como se pode ver numa casa já isolada no lote, localizada na Campina (Figura 35).

Outra tipologia que surge no Brasil durante os Oitocentos são as casas de porão alto. Estas primeiramente mantiveram sua implantação alinhada à rua, mas na segunda metade do século XIX houve o recuo dos limites laterais, mas em geral um dos lados mantinha alinhamento com a rua. Depois, novos partidos de edificações, em "U" e "T", começaram a ser usados, dessa forma iniciando o afastamento frontal da rua. ${ }^{38}$

Nessa região da cidade, predominam sobrados, que priorizavam o uso comercial no andar térreo e o habitacional nos andares superiores, alinhados na testada do lote e em uma das laterais do terreno, sendo a fachada lateral oposta recuada. Tais edificações seguiam o padrão usado tipicamente em Portugal no século XIX (Figuras 36 e 37).

Já no bairro da Cidade Velha, percebe-se que, quanto mais afastado da área portuária, menor é a quantidade de exemplares de imóveis com ornamentação na platibanda (Figura 38). 

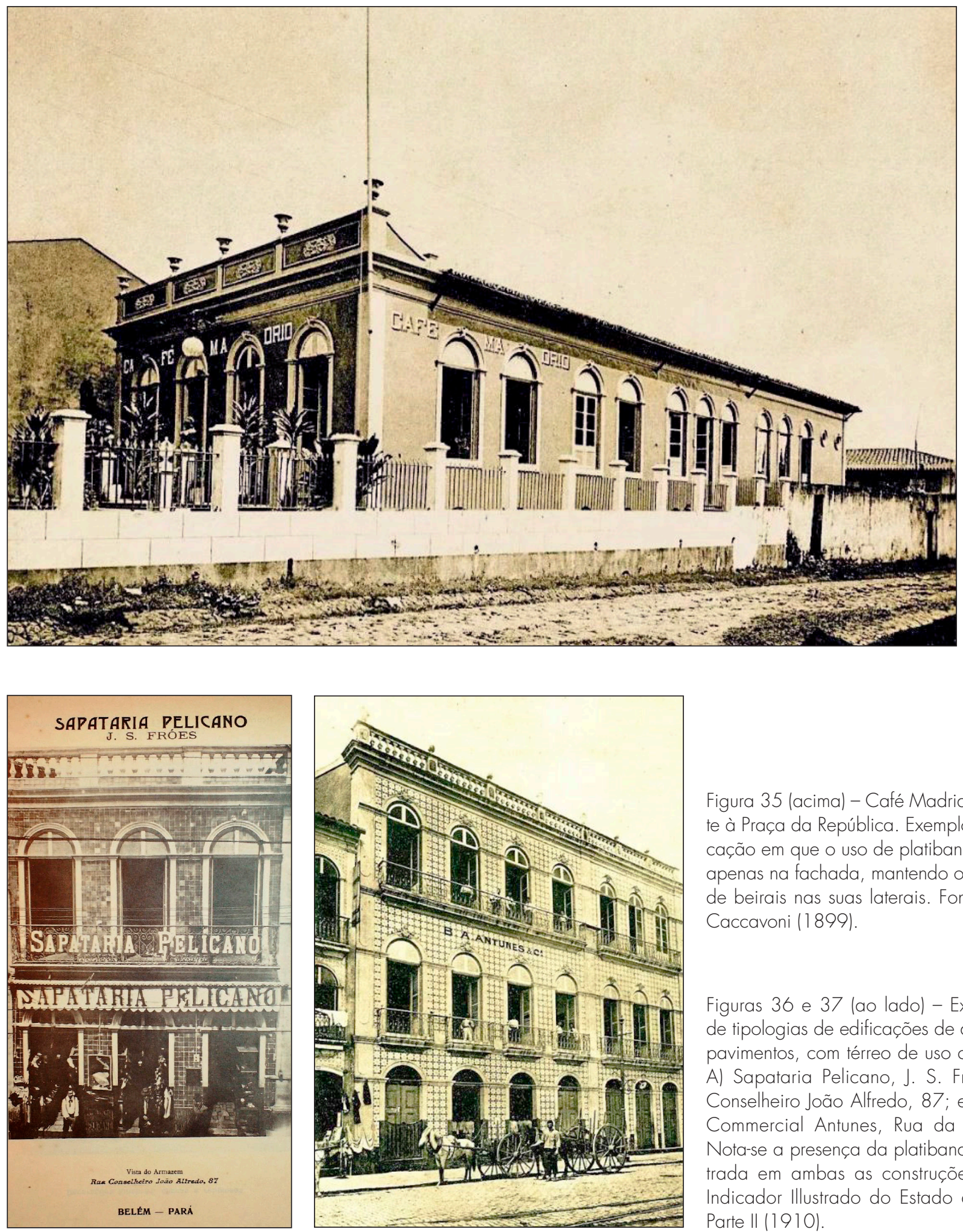

Figura 35 (acima) - Café Madrid, em frente à Praça da República. Exemplo de edificação em que o uso de platibanda estava apenas na fachada, mantendo o emprego de beirais nas suas laterais. Fonte: Arthur Caccavoni (1899).

Figuras 36 e 37 (ao lado) - Exemplares de tipologias de edificações de dois e três pavimentos, com térreo de uso comercial: A) Sapataria Pelicano, J. S. Frões, Rua Conselheiro João Alfredo, 87; e Bl Casa Commercial Antunes, Rua da Indústria. Nota-se a presença da platibanda balaustrada em ambas as construções. Fonte: Indicador Illustrado do Estado do Pará Parte II (1910). 


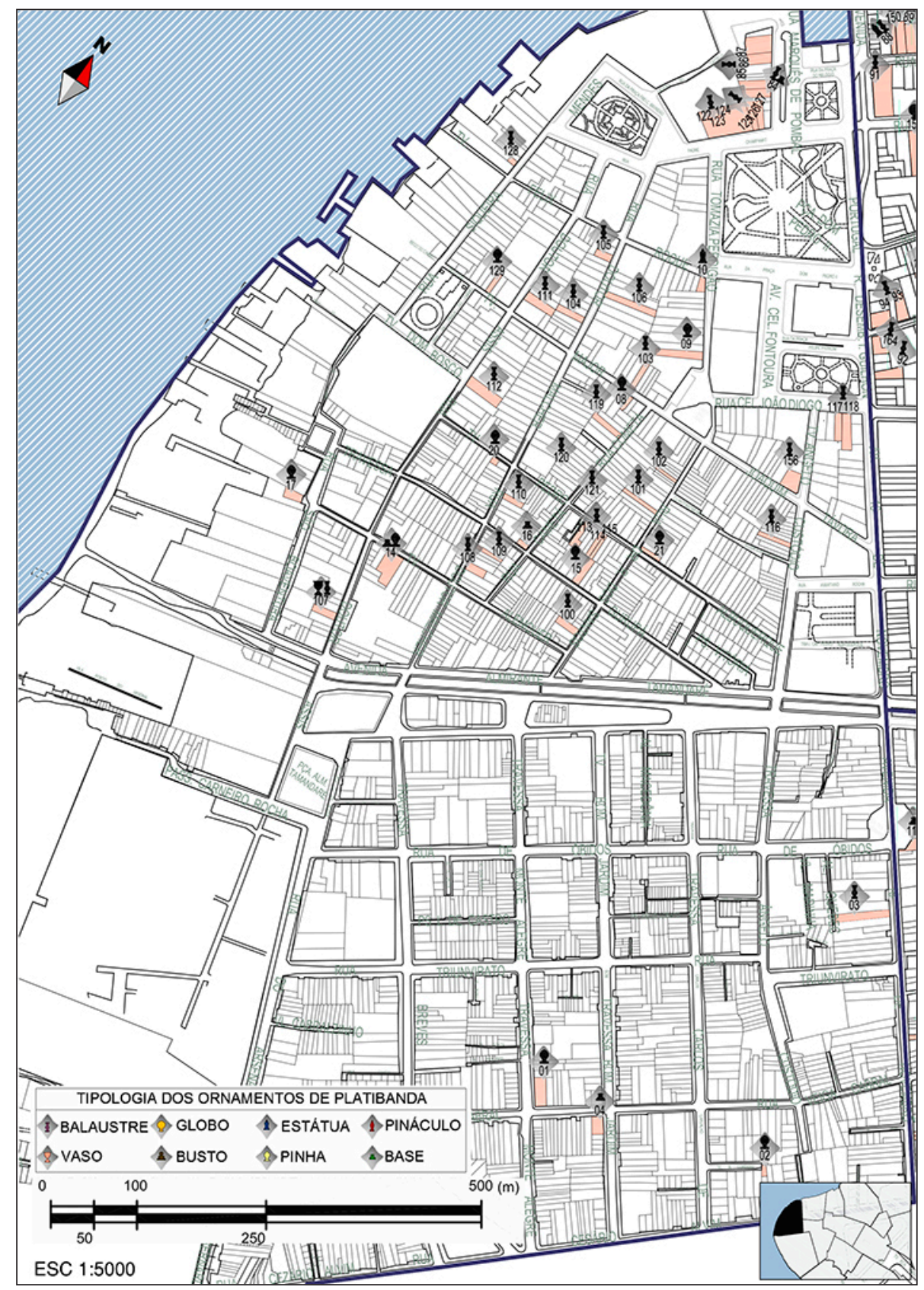

Figura 38 - Edificações com ornamentos de cerâmica vitrificada em platibanda no bairro da Cidade Velha.

Esse bairro consolidou-se como residencial ao longo do século XIX, tendo edificações térreas na sua maioria, que sofreram também influência do código de posturas de Antônio Lemos, como exemplo com as platibandas que foram inseridas 
em edificações já existentes. A gestão do Intendente Antônio Lemos não realizou obras importantes de alargamento na Cidade Velha, o que resultou numa manutenção do tecido urbano tradicional, com a manutenção das casas antigas alinhadas nas calçadas com reformas de adaptação. ${ }^{39}$

Na Belle Époque, o crescimento populacional duplicou e a elite abastada do período ansiava por vias projetadas, largas e arborizadas. Nesse sentido, entende-se porque a Cidade Velha perderá cada vez mais a função de abrigar esse segmento, função que será assumida pelo bairro de Nazaré, com áreas mais valorizadas e melhor infraestrutura, que passou a ser o eixo principal de circulação elitizada da cidade durante o século XX. Esse eixo foi traçado na planta de 1905, que priorizava a ligação do porto e do centro comercial da Campina à Estrada de Ferro de Bragança, por meio das atualmente denominadas avenidas Presidente Vargas, Nazaré, Magalhães Barata e Almirante Barroso. ${ }^{40}$

As plantas das novas construções nessa área seguiam os preceitos de higiene, clima e estética elaborados pela Legislação Municipal no período do intendente Antônio Lemos. A inserção das construções nos lotes obedecia ao alinhamento frontal das vias; o primeiro piso era elevado em relação ao nível do terreno; também havia padrões quanto a afastamentos laterais, à altura do pé direito e a dimensões de aberturas de janelas e portas. ${ }^{41}$ Durante o século XX, encontravam-se casas de subúrbios no bairro de Nazaré, as quais eram denominadas de rocinhas; as mesmas foram construídas no século XIX ou XX, momento em que essa região não era urbanizada, quando ali se construíam casas de campo. Essas casas não seguiam a regra de implantação tradicional no lote, pois eram situadas em vasto terreno com jardins ao seu redor. Receberam decoração eclética na sua fachada e inserção de platibanda, posteriormente a sua construção, seguindo o padrão decorativo que ocorria nos bairros anteriores. ${ }^{42} \mathrm{Em}$ Nazaré, entretanto, foram construídas novas tipologias de edificações, as quais Lemos cita como conceito de modernidade da época, como os mais importantes palacetes da cidade: Palacete Faciola, Palacete Barão de Guamá, Palacete Oliva, Palacete do governador Lauro Sodré, Palacete Bolonha, Palacete Montenegro, Palacete Bibi Costa, Palacete Chamié e outros pertencentes às famílias mais abastadas do início do século XX, 43 quase todos erguidos com outros repertórios decorativos, distantes das práticas decorativas de azulejos e platibandas decoradas, que ali ainda se manifestavam no Palacete Faciola.

A área de Nazaré inserida no Centro Histórico e seu entorno é uma pequena porção do bairro (Figura 39); sendo que foi possível identificar ali apenas uma edificação ornamentada. Mesmo não constando na região restrita de estudo, sabe-se da existência de outros exemplares presentes no restante bairro. Dada a
39. Ver Município de Belém (1897-1902).

40. Ver Celio Claudio de Queiroz Lobato et al. (2005).

41. Ver Município de Belém (1907).

42. Ver Carmen Lúcia Valério Cal (1989).

43. Ver Celio Claudio de Queiroz Lobato et al. (2005). 
relevância e requinte que esse bairro teve na fase áurea da borracha, mostrase a necessidade de aprofundar posteriormente a análise e cadastro dessa região expandida.

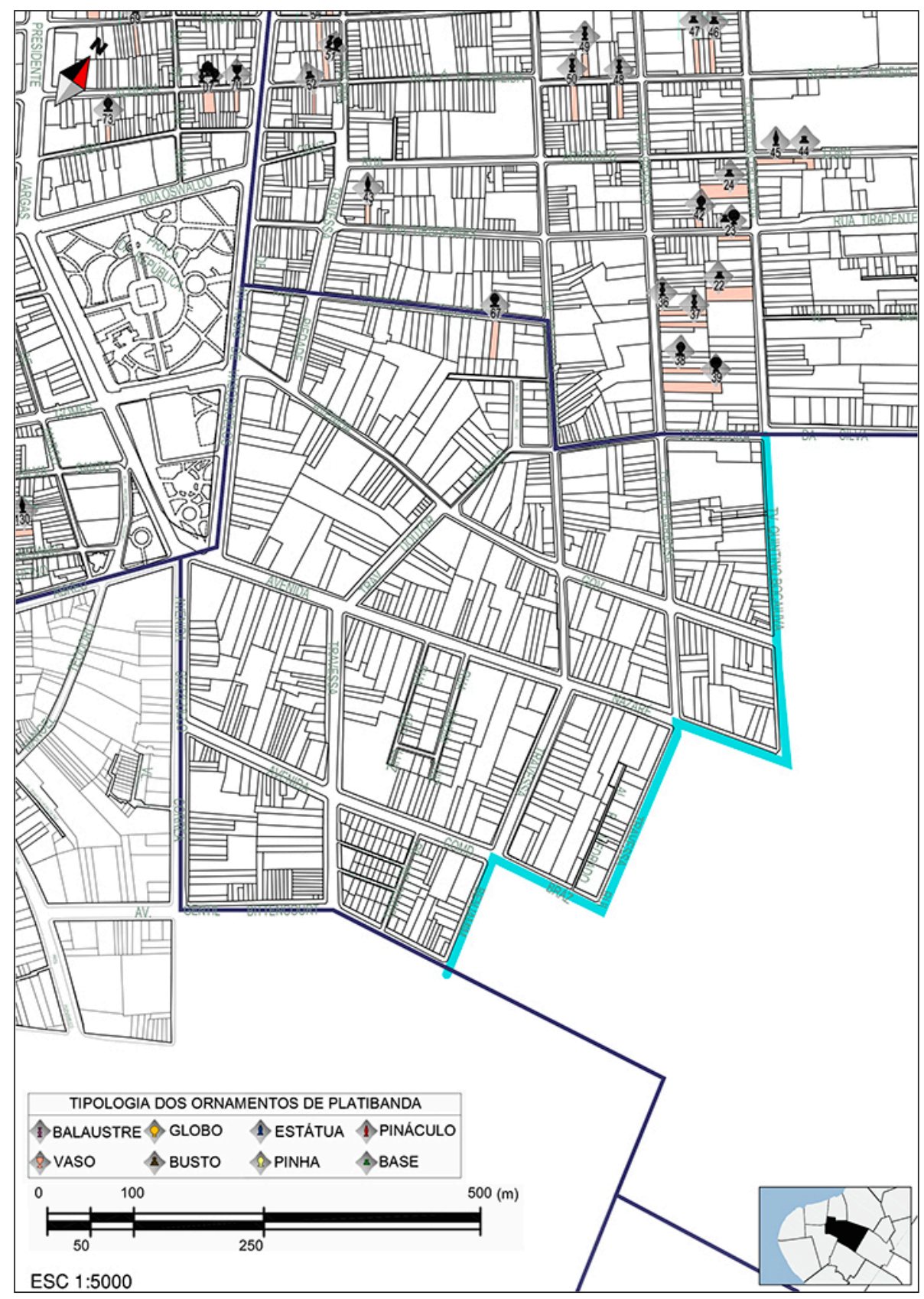

Figura 39 - Edificação com ornamentos de cerâmica vitrificada em platibanda na porção do bairro da Nazaré que se enquadra no Centro Histórico de Belém. 
Bairro do Reduto, o qual foi destinado à zona de bairro industrial, comercial e de prestação de serviços devido a sua localização próxima do porto, beneficiou-se de áreas aterradas pelo plano urbanístico de Antônio Lemos. ${ }^{44}$

Nesse bairro havia indústrias, armazéns, fábricas, oficinas, lojas, galpões e vilas de trabalhadores das respectivas fábricas. Em 1910, Lemos adotou política de concessões para realizar o saneamento, urbanização e construção do Mercado do Reduto. ${ }^{45}$ A grande quantidade de ornatos que interessam a este artigo nesse bairro ocorre possivelmente devido à proximidade com o porto e ao período de ocupação urbana que ocorreu no auge da Belle Époque (Figura 40). Vale ressaltar que a ornamentação de cerâmica vitrificada também foi usada nos pórticos de vilas operárias, como é possível observar na Rua 28 de Setembro, situada no ícone 60 do mapa (Figuras 41 a 44).

No ano de 1820, uma região de terreno pantanoso e com vegetação alta, denominada de Largo de Sergipe, foi entregue para a ocupação da população menos abastada. ${ }^{46}$ Em 1905, Antônio Lemos aterrou grande trecho das zonas baixas do bairro Batista Campos, ${ }^{47}$ último dos que compõe o perímetro do Centro Histórico e entorno, que focalizamos neste trabalho

A região correspondente a esse bairro apenas contém cinco edificações ornamentadas (Figura 45). $\bigcirc$ desenvolvimento desse bairro se deu inicialmente para uso residencial de pessoas com menos posses, o que posteriormente mudou com a reforma da Praça Batista Campos em 1904 inaugurada por Lemos, que valorizou a região.

\section{NÚMERO DE PAVIMENTOS E O USO DE DECORAÇÃO MISTA DE ORNAMENTOS POR BAIRRO DO CENTRO HISTÓRICO E ENTORNO}

Entre as 225 edificações inventariadas, observou-se que a maior parte das edificações tem ornamentos de platibanda; 60 edificações têm térreo com porão, seguidas das 55 edificações de dois pavimentos, 50 de um pavimento), 40 com térreo sem porão, 19 com três pavimentos e uma única edificação de quatro pavimentos (Figura 46).

Quanto ao tipo de ornamento utilizado na fachada, é comum utilizar mais de um tipo na mesma platibanda nas construções neoclássicas e ecléticas, porém, na cidade de Belém observou-se que apenas 10\% das edificações catalogadas, vinte e quatro ao todo, apresentam a decoração mista, estando a maior parte (71\%) localizada no bairro da Campina, seguido de Cidade Velha e Reduto, com três
44. Ver Celio Claudio de Queiroz Lobato et al. (2005).

45. Ver Carlos Rocque (1973).

46. Ver Elizabeth Nelo Soares (2009).

47. Ver Carlos Rocque (1973). 
imóveis em cada, e o bairro de Batista Campos, com apenas uma edificação com essa composição (Figura 47).

uso de mais de um tipo de ornamento em platibanda é comum no Brasil, contudo, na cidade de Belém é possível constatar que, aproximadamente 10\%, ou seja, 24 dos imóveis catalogados, têm essa decoração mista.

Figura 40 - Edificações com ornamentos de cerâmica vitrificada em platibanda na porção do bairro da Reduto, que se enquadra no Centro Histórico de Belém.

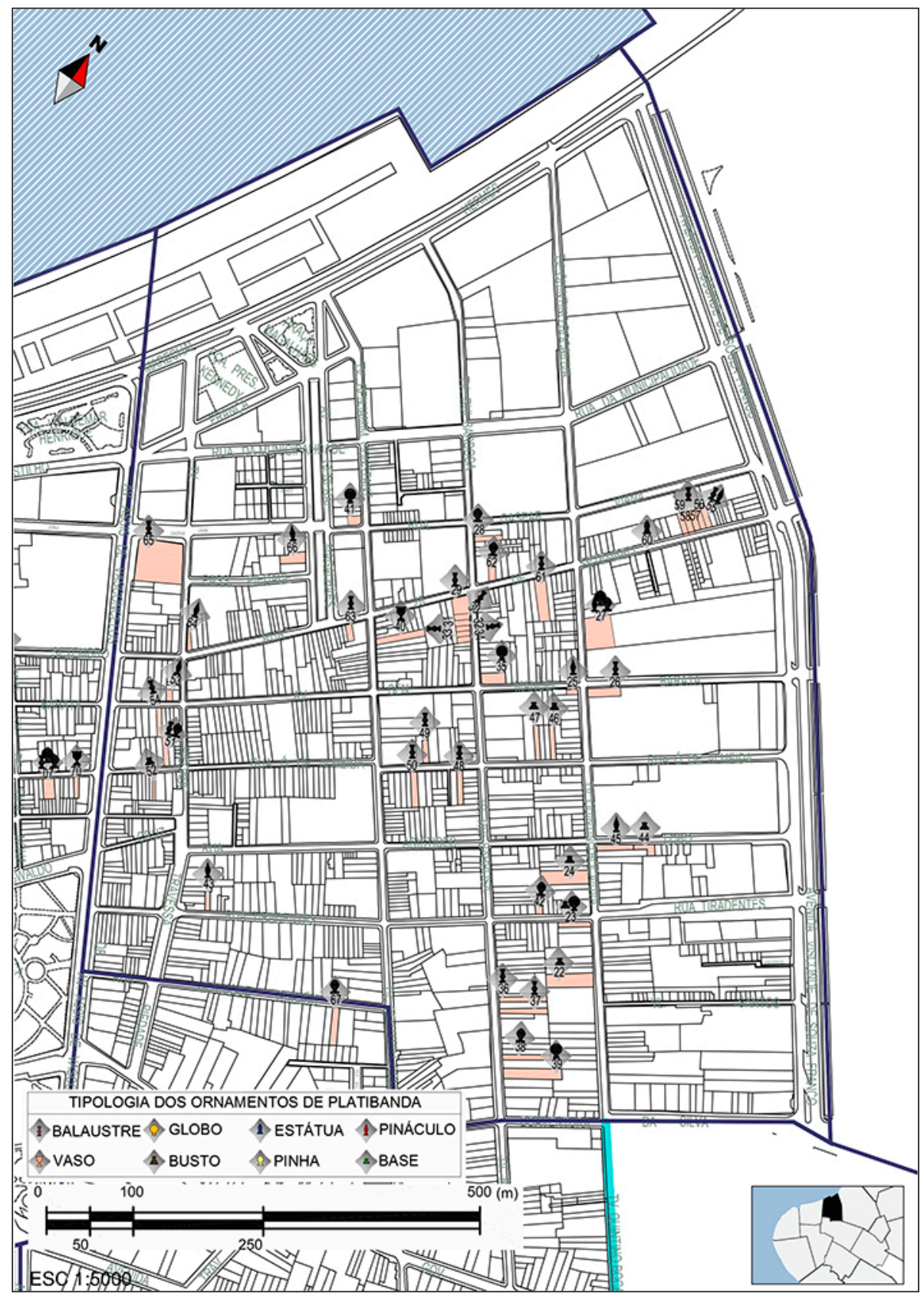




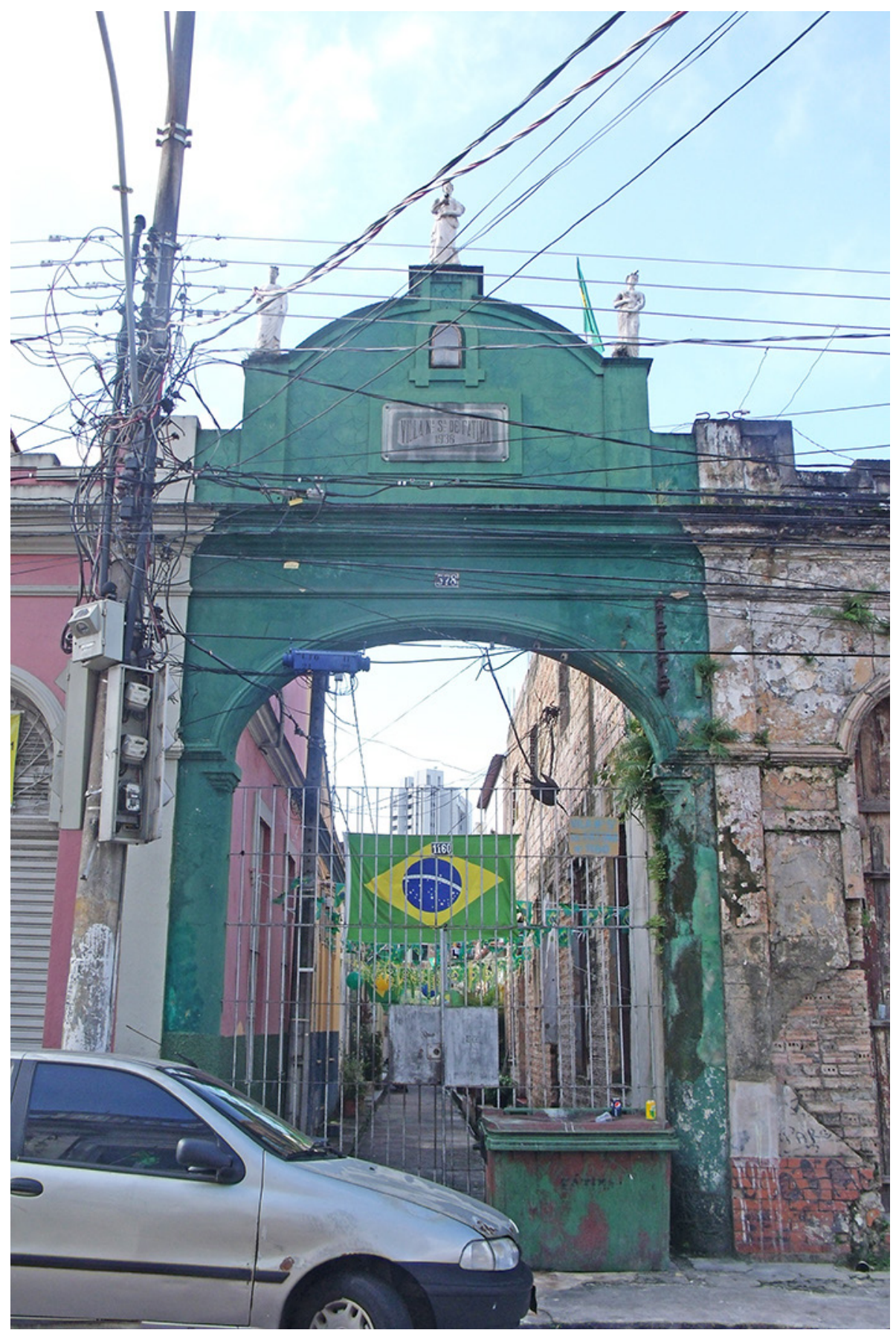

Figuras 41, 42, 43 e 44 - Pórtico da vila operária localizada no bairro do Reduto com três estátuas de cerâmica vitrificada. 

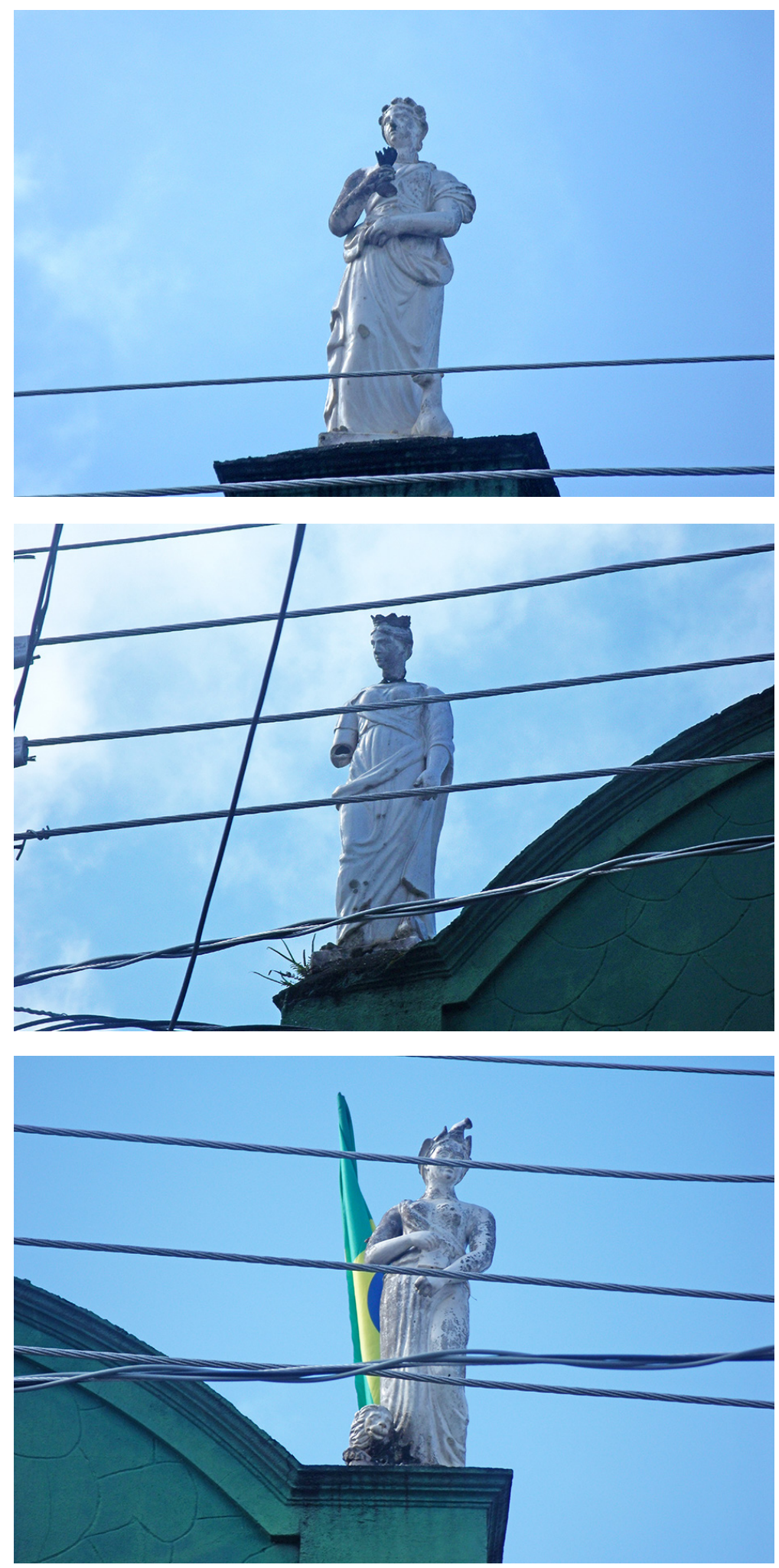


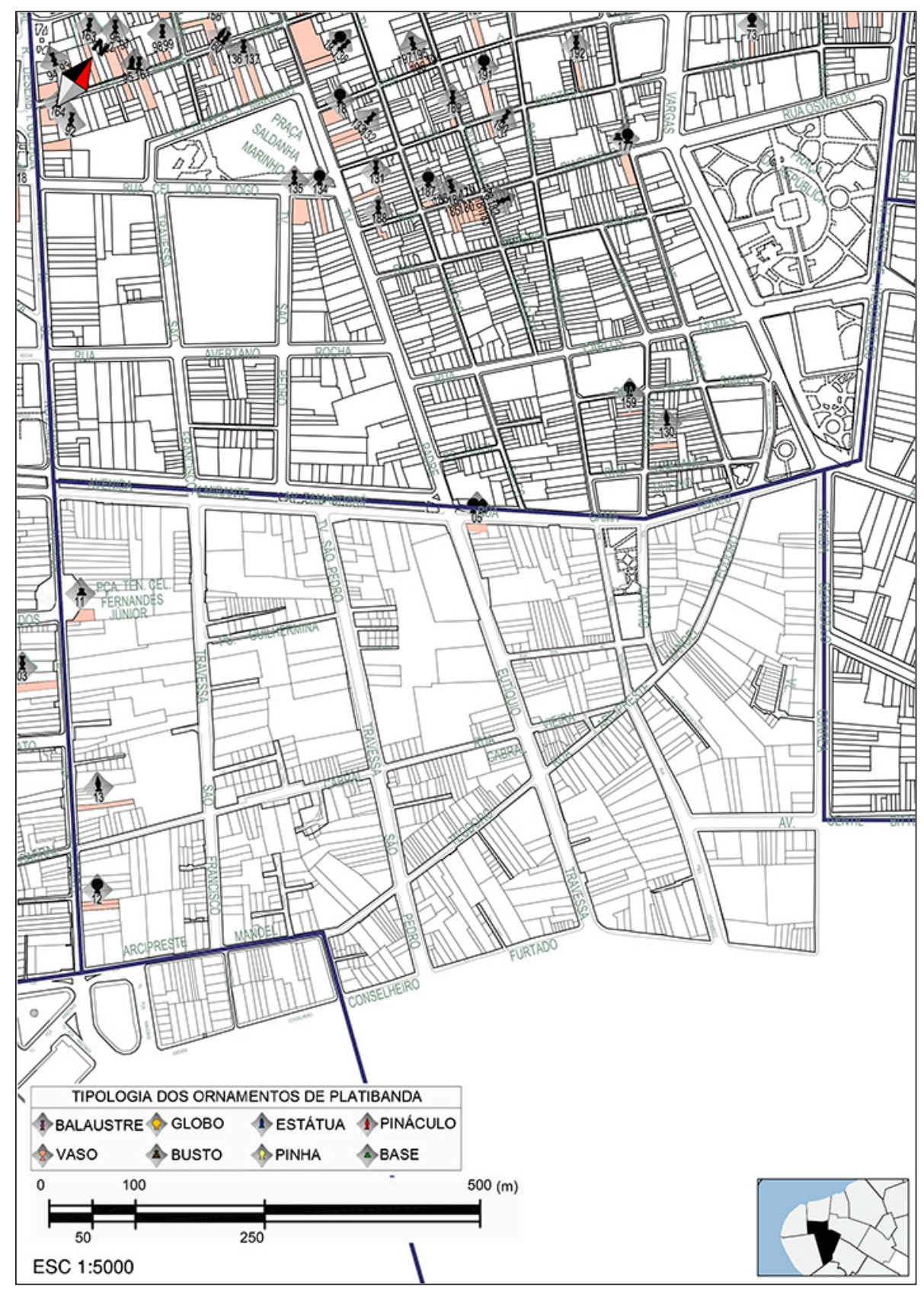

Figura 45 - Edificações com ornamentos de cerâmica vitrificada em platibanda na porção do bairro Batista Campos, que se enquadra no Centro Histórico de Belém. 


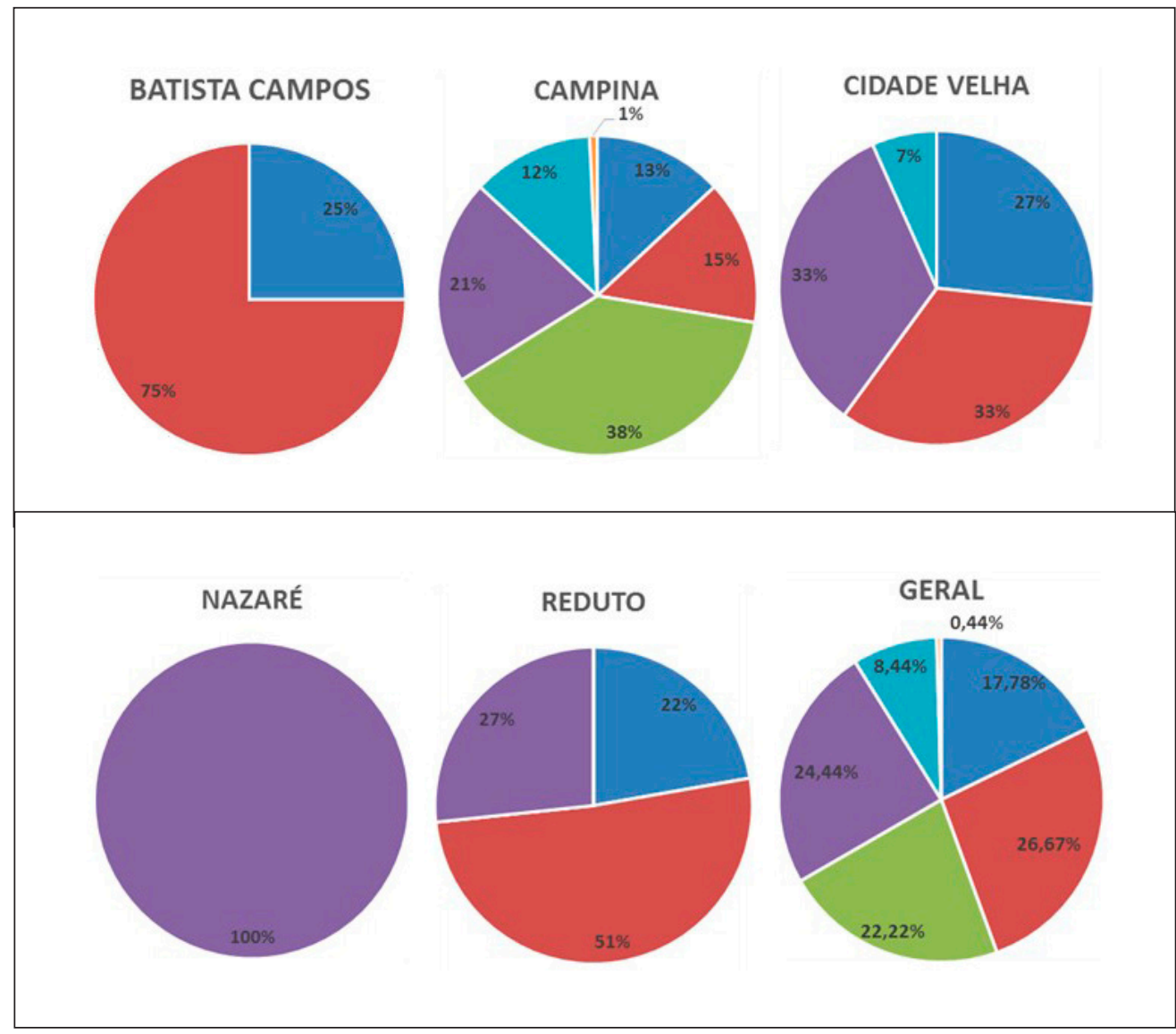

Figura 46 - Gráficos referentes ao número de pavimentos por edificação com ornamentação em platibanda existentes nos bairros do Centro Histórico e seu entorno.

Térreo

- Térreo + Porão

- $1^{\text {a }}$ Pavimento

- $2^{a}$ Pavimento

- $3^{\text {a }}$ Pavimento

- 4 a Pavimento

\section{ORNAMENTAÇÃO MISTA}

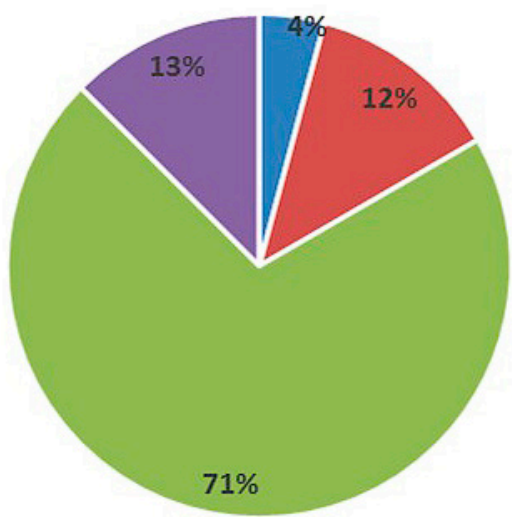

Figura 47 - Edificações que utilizam mais de um tipo de ornamento por bairros do Centro Histórico e seu entorno.

- Batista Campos

Cidade Velha

- Campina

Reduto

- Nazaré 
Os ornatos de cerâmica vitrificada em Belém estão sujeitos às alterações (2007). provocadas pelas intempéries do clima tropical de forma intensa, devido à localização das edificações na zona equatorial, o que as expõe à luz intensa do Sol e às águas das chuvas. Além disso, tais ornamentos entram em contato com a polvição do ar, excremento de aves e até mesmo atos de incivilidade humana.

As alterações observadas no elenco de ornamentos localizados no Centro Histórico de Belém e seu entorno assemelham-se àquelas dos padrões identificados nos azulejos de fachada por Sanjad ${ }^{48}$ e correspondem a: 1) Agentes físicos como fratura, fissura, perda do material cerâmico, destacamento do vidrado, preenchimento, pintura incompatível, craquelê, trinca, sujidades, deposito de sujidades entre a base cerâmica e o vidrado, sujidades que podem estar depositadas acima ou na sua interface, ranhura, vacúolo e ação humana inadequada; 2) Agentes biológicos pela presença de vegetais superiores e manchas causadas provavelmente por microrganismos (algas da divisão das cianofíceas); 3) Agentes químicos, como eflorescência salina, perda do brilho, descoloração, coloração (Figura 48).

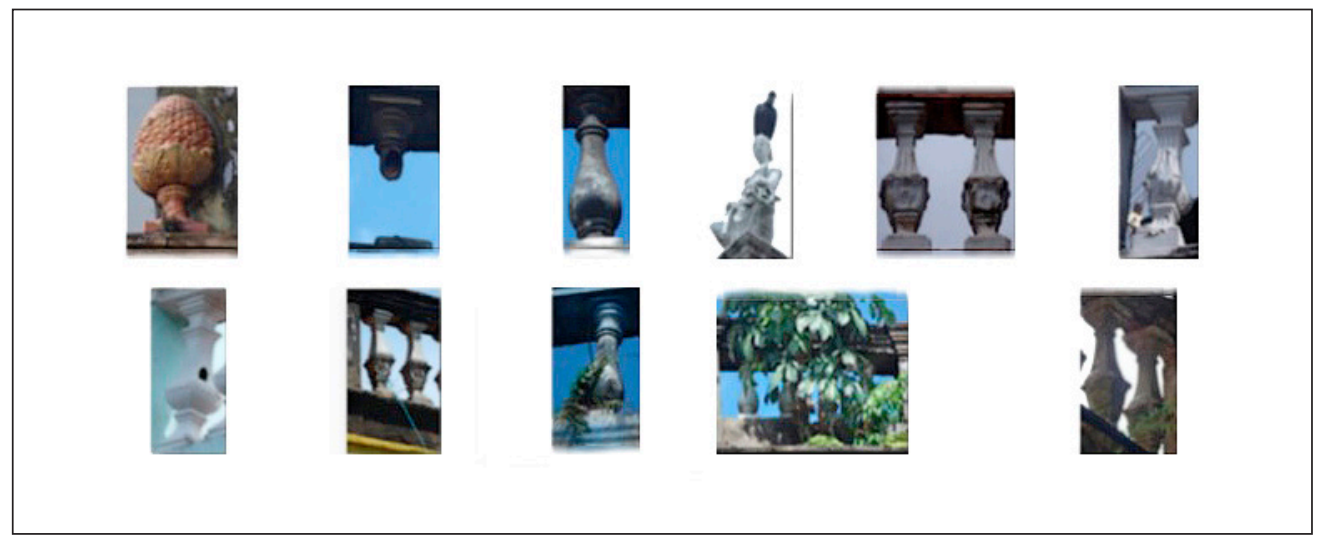

Figura 48 - Patologias - Alterações encontradas no Centro Histórico e entorno da cidade de Belém do Pará.

A alteração mais frequente nos ornamentos, $29 \%$ do geral, corresponde à pintura das peças, o que dificulta a identificação do tipo de material e muitas vezes as feições dos desenhos que compõem o ornamento.

A presença de microrganismos em mais de $28 \%$ desses ornatos era esperada, pois o clima e a umidade da cidade de Belém propiciam a proliferação desses seres. A existência de microrganismos causa uma sequência de danos à 
peça, como exemplo a fissura, o destacamento e ocasionalmente a perda de massa, mas esta é apenas uma variável que pode ocasionar essas deteriorações.

A perda de brilho, presente em 3\% dos ornatos das edificações catalogadas, pode ser ocasionada pelo excesso de exposição ao sol, aos ventos e à chuva, pelo desgaste e até pela alteração na composição da superfície vitrificada.

A presença de vegetação em 13\% do total dos imóveis analisados na platibanda demonstra o descaso com a preservação da própria edificação, pois, um vegetal superior presente na fachada demanda muito tempo para seu crescimento, e quando ocorre se fixa com raiz profunda, o que causa danos estruturais à fachada da edificação e consequentemente perda e desagregação das peças que nela se encontram (Figura 49).

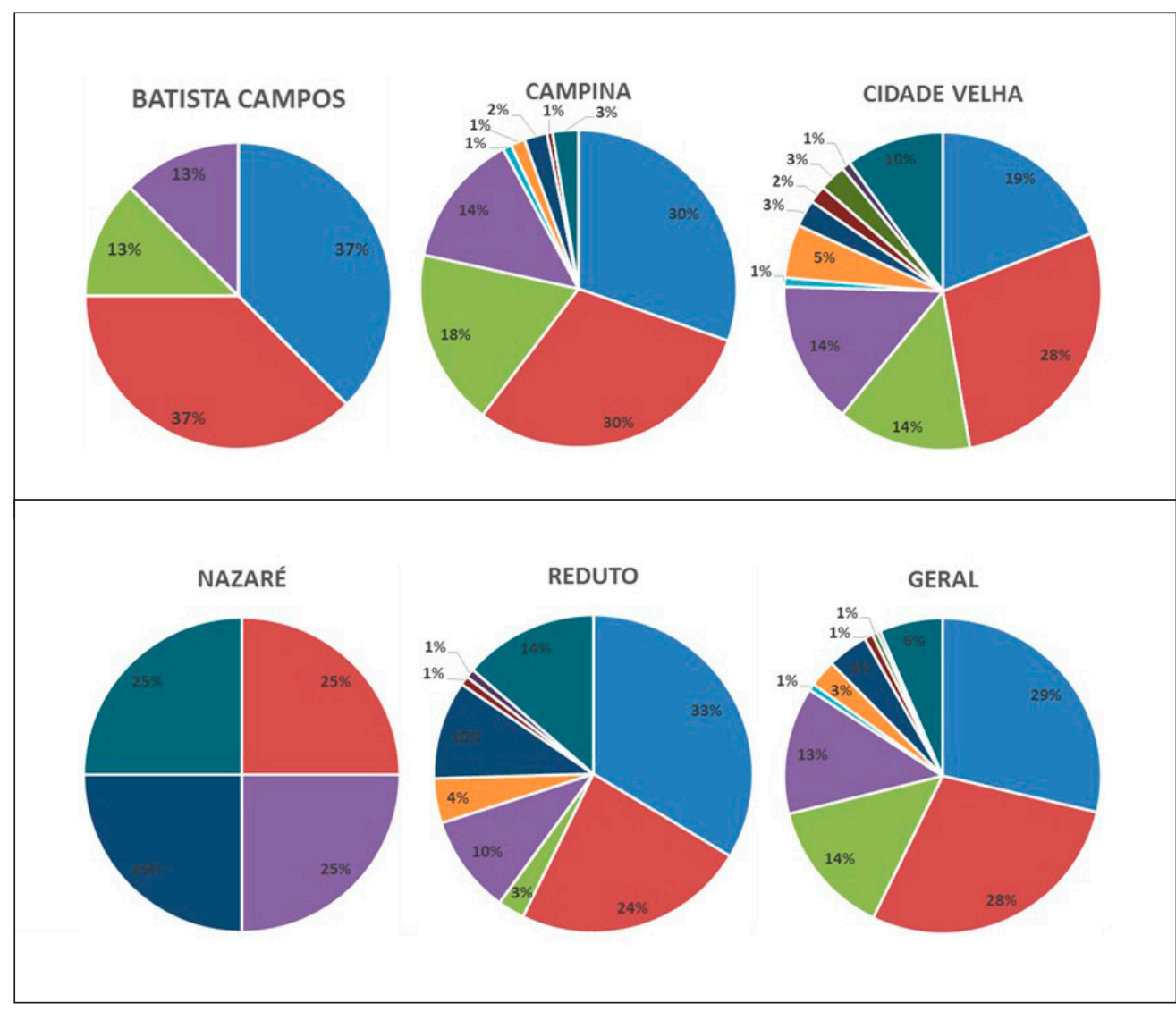

Pintado

Microorganismo

Destacamento

Vegetação

- Lacuna

Perda de brilho

- Perda de massa

- Aves

Fissura

Outro material

- Novo

Figura 49 - Gráficos referentes às alterações encontradas nos ornamentos por edificação dos bairros do Centro Histórico e seu entorno. 
Dos cento e oitenta e dois (182) padrões de ornamentos diferentes nos imóveis, 78,45\% encontram-se em bom estado de conservação, o que representa a resistência e boa adaptação dessas peças ao clima da região. Apesar disso, vinte e uma (21) edificações têm lacunas de seus ornamentos e outras vinte e uma (2 1 ) estão em péssimo estado de conservação (Figura 50).

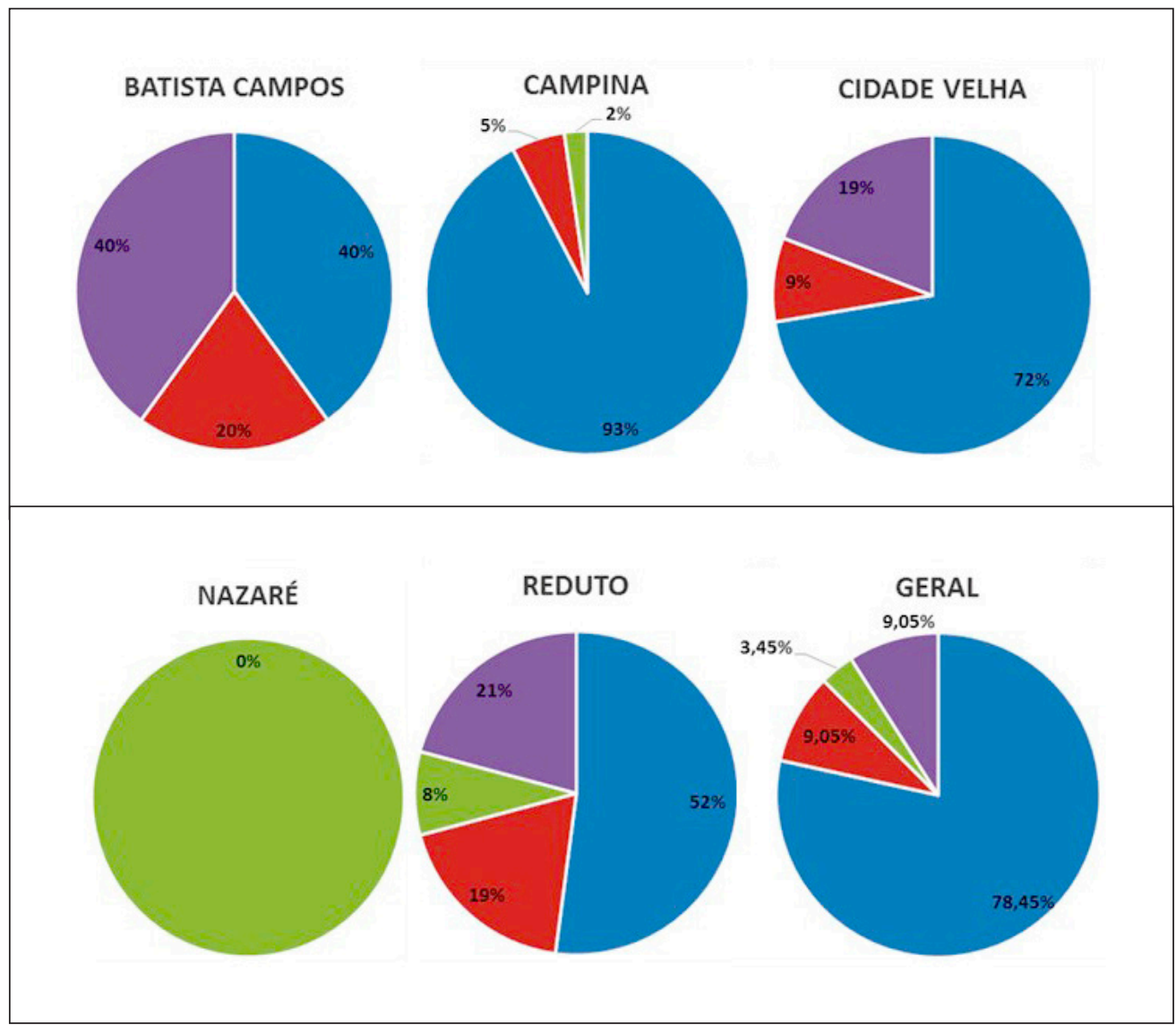

Figura 50 - Gráficos referentes ao estado de conservação dos ornamentos em platibanda existentes e os bairros do Centro Histórico e seu entorno.

O estado de conservação do imóvel que contém a ornamentação de platibanda é um fator influenciador, por apresentar maior risco direto na peça devido à quantidade de intempéries que o ambiente apresenta, mas não está diretamente ligado à conservação dos ornamentos, como é possível notar na relação dos dados do estado de conservação das peças com o dos imóveis. Das edificações neoclássicas e ecléticas analisadas, 87,56\% encontram-se em bom estado de conservação, 10,22\% estão em estado precário e 1,78\% está em arruinamento, com 0,44\% já em estado arruinado (Figura 51 ). 


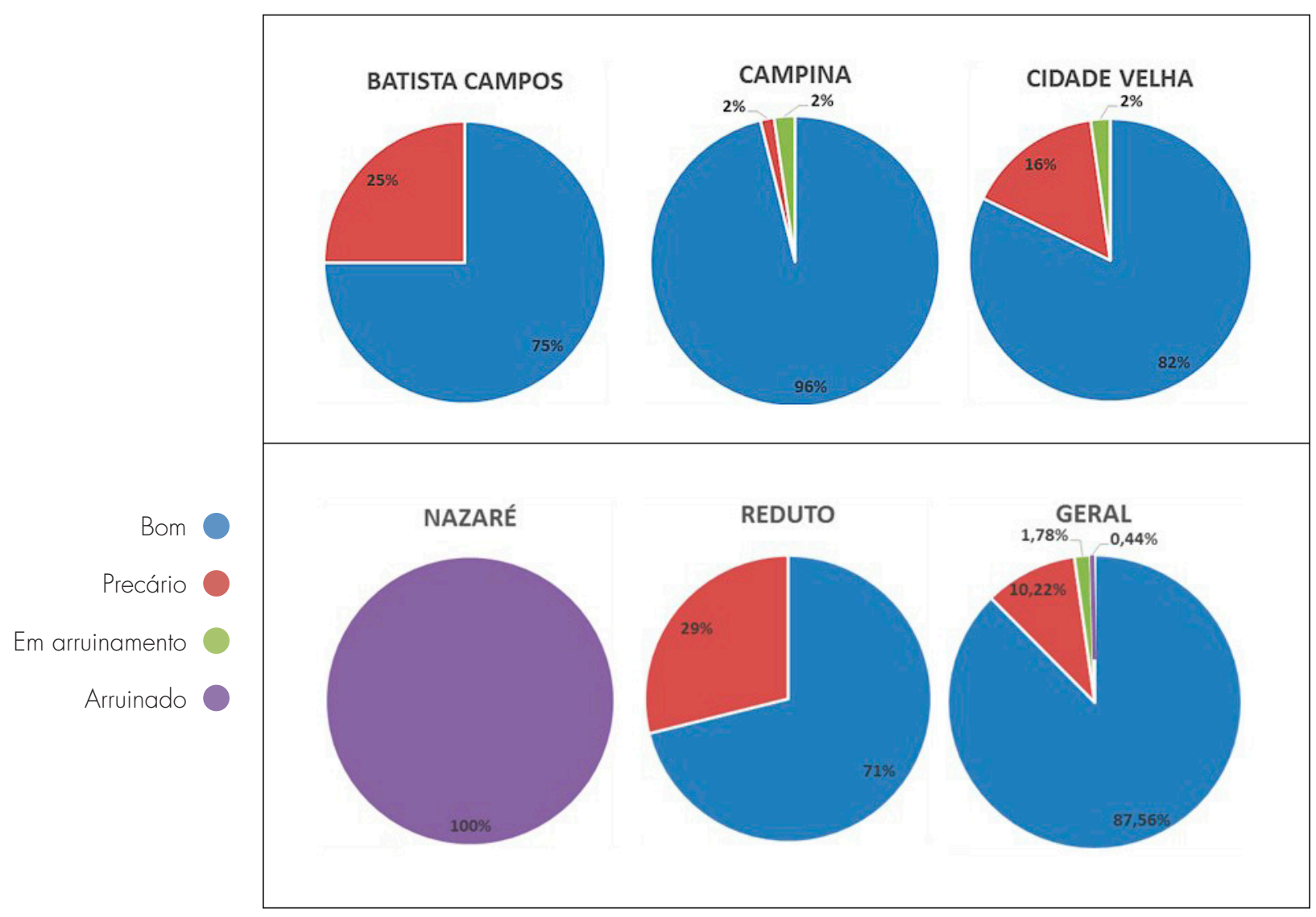

Figura 51 - Gráficos referentes ao estado de conservação do imóvel com ornamentos em platibanda existentes nos bairros do Centro Histórico e seu entorno.

As deteriorações em peças de cerâmica vitrificada ocorrem na base cerâmica ou na camada vitrificada, e há dificuldade na percepção de representativa porcentagem das peças, devido ao fato de a grande quantidade de ornatos estar pintada, não sendo possível identificar o material de que são feitos. No entanto, é notável que a deterioração mais presente é causada por microrganismos, devido principalmente à umidade relativa da cidade de Belém, que propicia sua proliferação. Sabe-se que pontos que estão deteriorados tornam-se mais suscetíveis a outros danos, o que torna ainda mais relevante a necessidade de aprofundamento no conhecimento técnico do material destes ornatos para que sejam realizados procedimentos de restauro adequado. 


\section{CONCLUSÕES}

Os ornamentos de cerâmica vitrificada do Centro Histórico de Belém e seu entorno estão concentrados nessa região devido ao período histórico da evolução urbana da cidade corresponder ao século XIX, quando a cultura arquitetônica europeia era vigente, pois a elite local fazia altos investimentos para a sofisticação dos costumes.

A arquitetura neoclássica e eclética caracteriza-se por revivalismos e, no caso dos ornamentos em questão neste artigo, resgata e reelabora modelos clássicos da antiguidade romana. As simbologias dos ornamentos nas edificações representavam erudição e reforçavam as virtudes defendidas no período. É de grande relevância cultural que esses ornamentos sejam conservados nas platibandas, visto que esse modelo de decoração de fachadas marca um período de riqueza e sofisticação que caracteriza a época áurea da borracha. Os exemplares existentes sofrem o processo acelerado de subtração de ornamentos de platibanda das edificações em vários casos na cidade, e isso continua ocorrendo de forma crescente (Figuras 52 e 53).

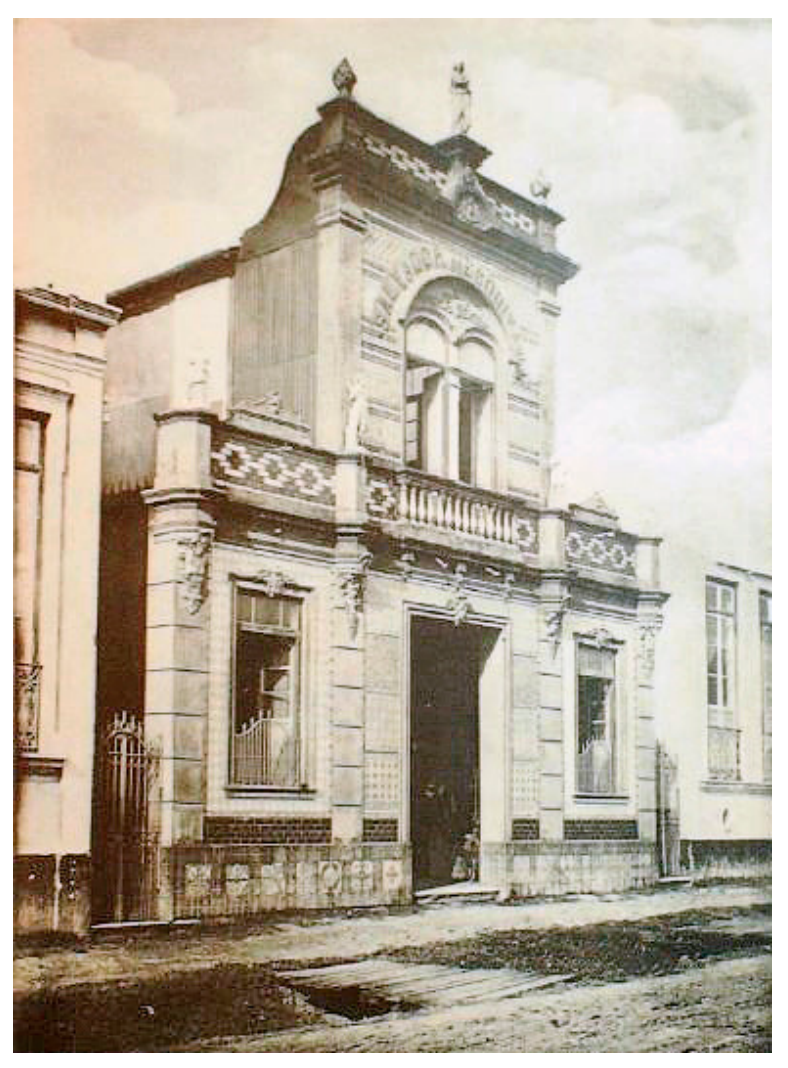

Figuras 52 e 53 - Exemplar da fachada descaracterizada de um antigo estabelecimento de vendas de materiais de construção, "Salvador, Mesquita \& $C^{a}$ Constructores", localizado na Travessa São Francisco, n 10, em Belém do Pará. Na primeira imagem, vê-se o imóvel no ano de 1910 e a segunda fotografia data de 2016, em que se nota a descaracterização do imóvel. Referente aos ornamentos, observa-se - desaparecimento da estátua, que adornava o centro da platibanda, das duas pinhas que ornavam as pontas e de quatro estátuas, que se situavam na altura do balcão, na direção da marcação de quatro colunas. Fonte: Indicador Illustrado do Estado do Pará - Parte II (1910). Na página ao lado, fotografia de Tainá Arruda, 2015. 


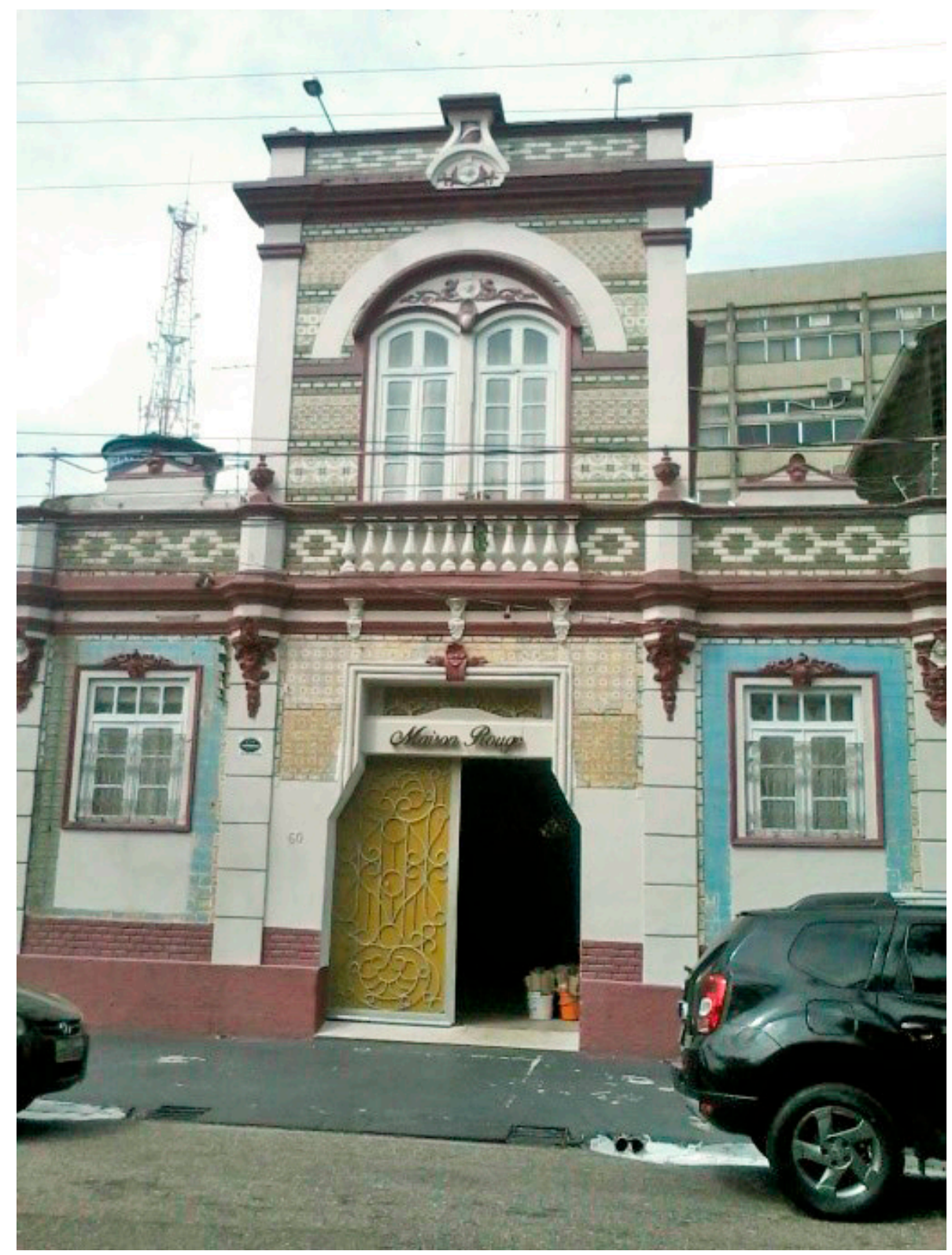

bairro com a maior concentração de ornamentos de cerâmica vitrificada é o da Campina, seguido pelo bairro do Reduto e da Cidade Velha. Os bairros mais distantes da Cidade Velha, tais como Nazaré e Batista Campos, passaram por um maior processo de modificação na estrutura original de suas edificações ou mesmo por substituição total das construções, o que provavelmente ocasionou a perda de inúmeros exemplares de edificações com 
ornamentação de platibanda. Até a edição da Lei n 7.709 de 1994 e do Plano Diretor urbano com diretrizes que levam em consideração as leis de preservação não havia uma legislação específica de proteção para o conjunto do Centro Histórico e seu entorno, o que não impediu descaracterizações e até mesmo destruição de boa parte desse patrimônio.

Vale ressaltar a proteção federal realizada mais recente por meio do tombamento dos bairros da Cidade Velha e Campina em 2012, que abrange aproximadamente 2.800 edificações protegidas, que estão certamente entre as mais numerosas e representativas do Brasil. Tal fator pode ter contribuído também para a preservação das ocorrências estudadas neste artigo.

Seria de grande relevância para a preservação dos ornamentos se houvesse subsídios de conservação especificados na legislação e no Plano Diretor; tal instrumento reforçaria a necessidade da salvaguarda dos mesmos nas platibandas.

A cidade de Belém possui outros exemplares de edificações com decorações de ornamentos vitrificados em platibanda, inclusive nas porções dos bairros que não foram analisados; contudo, a região selecionada para a análise, de fato, é a que possui maior relevância histórico-cultural e maior concentração de exemplares de arquitetura neoclássica e eclética. 


\section{REFERÊNCIAS}

AlBERNAZ, Maria Paula; LIMA, Cecilia Modesto. Dicionário ilustrado de arquitetura. Volume II - J a Z. São Paulo: ProEditores, 1998.

CACCAVONI, Arthur. Album descriptivo amazonico. Genova: F. Armanino, 1899.

CAL, Carmen Lúcia Valério. Esboço da evolução da arquitetura residencial em Belém na primeira metade do século. Revista do Tecnológico, Departamento de Arquitetura da Universidade Federal do Pará, Belém, vol. 2, p. 64-83, jan.-jun. 1989.

CARVALHO, Anna Cristina Rodopiano de; MARQUES JÚNIOR, Arnaldo Ferreira. Inventário de estilos arquitetônicos da cidade de Santos. Santos: E\&M Ensino e Memória; Prefeitura Municipal de Santos, 2011.

CATÁLOGO da fábrica de cerâmica e fundição das Devesas - Antonio Almeida da Costa \& Cia.. Vila Nova de Gaya: [s.n.], 1910.

CRUZ, Ernesto. As edificações de Belém: 1783-1911. Belém: Conselho Estadual de Cultura do Pará, 1971. (Coleção História do Pará, Série Arthur Vianna).

DOMINGUES, Ana Maria Portela. A ornamentação cerâmica na arquitectura do Romantismo em Portugal. Tese (Doutorado em História da Arte) - Faculdade de Letras da Universidade do Porto, Porto, 2009.

FERREZ, Gilberto. Iconografia do Rio de Janeiro, 1530-1890: catálogo analítico. Rio de Janeiro: Casa Jorge Editorial, 2000. 2 v.

GOVERNO DO ESTADO DO PARÁ. Álbum do Pará em 1899: na administração de sua excia. o sr. dr. José Paes de Carvalho. Belém: Felipe Augusto Fidanza, 1899.

INDICADOR Ilustrado do Estado do Pará. Rio de Janeiro: Courrier \& Billiter, 1910.

LEIS, Resoluções Municipaes e Actos do Executivo, 1905. Acervo do Arquivo Público do Estado do Pará, Belém. 
LOBATO, Celio Claudio de Queiroz; ARRUDA, Euler Santos; PALHETA JUNIOR, Francisco Xavier; PONTE, Juliano Pamplona Ximenes; PONTE, Manfredo Ximenes; POMBO, Tereza Cristina Barbosa da Silva. Um olhar sobre aspectos da infraestrutura e do planejamento urbano em Belém do Pará. Belém: CESUPA, 2005.

MAGALHÃES, Cristiane Maria. A arte de modelar a paisagem: os ornatos de arquitetura para jardins no ecletismo do paisagismo brasileiro. Revista Espaço Acadêmico, Maringá, v. 13, n. 156, maio 2014.

Indústria, técnica e arte da azulejaria, faiança e cerâmica: o mobiliário luso-brasileiro dos jardins no período eclético do paisagismo brasileiro. In: CONGRESSO INTERNACIONAL SOBRE PATRIMÓNIO INDUSTRIAL, II, 2014, Porto. Património, museus e turismo industrial: uma oportunidade para o século XXI. Porto: Universidade Católica do Porto, 2014.

MASCARENHAS, Alexandre. Antônio Francisco Lisboa: moldagens de gesso como instrumento de preservação da sua obra e o processo construtivo nas oficinas de escultura em Portugal a partir do século XVIII. Belo Horizonte: Fino Traço, 2014.

Ornatos: restauração e conservação. Rio de Janeiro: In-fólio, 2008. (Coleção Artes \& Ofícios - Monumenta).

MEIRA FILHO, Augusto. Evolução histórica de Belém do Grão-Pará: fundação e história, 16161823. 2. ed. Belém: M2P Arquitetura e Engenharia, 2015.

MUNICÍPIO de Belém (1897-1902: Antônio José Lemos): relatório apresentado ao Conselho Municipal de Belém na sessão de 15 de novembro de 1902 pelo Intendente Senador Antonio José Lemos. Belém: Typographia de Alfredo Augusto Silva. 459p.

MUNICÍPIO DE BELÉM (1904: Antônio José Lemos): relatório apresentado ao Conselho Municipal de Belém na sessão de 15 de novembro de 1905 pelo Intendente Senador Antonio José Lemos. Belém: Archivo da Intendência Municipal. 327p.

MUNICÍPIO DE BELÉM (1906: Antônio José Lemos): relatório apresentado ao Conselho Municipal de Belém na sessão de 15 de novembro de 1907 pelo Intendente Senador Antonio José Lemos. Belém: Archivo da Intendência Municipal. v. 5, 262p.

OURIQUE, Jacques. O Estado do Pará na Exposição Nacional do Rio de Janeiro em 1908. Rio de Janeiro: Typographia Leuzinger, 1908.

PAIS, Alexandre Nobre. Um tema de fachada: a escultura cerâmica portuguesa no exterior de arquitecturas luso-brasileiras. Portal Vitruvius. Disponível em: <http://www.vitruvius.com.br/ revistas/read/arquitextos/13.148/4484>, acesso em 15/09/2012. 
REIS FILHO, Nestor Goulart. Quadro da arquitetura no Brasil. 10. ed. São Paulo: Perspectiva, 2004.

ROCQUE, Carlos. Antônio Lemos e sua época: história política do Pará. Belém: Amazônia Edições Culturais, 1973.

SANJAD, Thais Alessandra Bastos Caminha. Intemperismo tropical em fachadas azulejadas de edificações históricas de Belém do Pará. Tese (Doutorado em Ciências - Geologia e Geoquímica) - Universidade Federal do Pará, Belém, 2007.

Patologias e conservação de azulejos: estudo tecnológico de conservação e restauração com azulejos dos séculos XVI, XVII e XIX pertencentes às cidades de Belém e Salvador. Dissertação (Mestrado em Arquitetura e Urbanismo) - Universidade Federal da Bahia, Salvador, 2002.

SCOLARI, Keli Cristina; GONÇALVES, Margarete Regina Freitas. Identificação de cerâmicas em faiança portuguesa nos casarões do centro histórico da cidade de Pelotas, Rio Grande do Sul. Museologia e Patrimônio, Rio de Janeiro: Unirio; MAST, v. 6, n. 1, 2013.

SOARES, Elizabeth Nelo. Largos, coretos e praças de Belém. Brasília: Programa Monumenta, 2009.

VOLPATO, Gilson Luiz. Guia prático para redação científica. Botucatu: Best Writing, 2015.

Artigo apresentado em 29/09/2016. Aprovado em 07/02/2017.

All the contents of this journal, except where otherwise noted, is licensed under a Creative Commons Attribution License

\section{(cc) BY}

